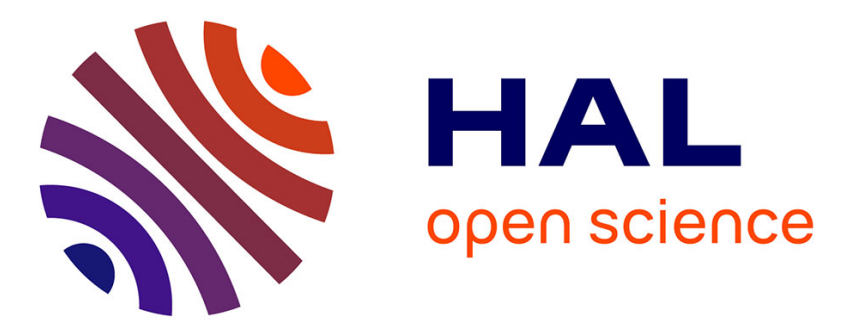

\title{
SIMS chlorine isotope analyses in melt inclusions from arc settings
}

Mélina Manzini, Anne-Sophie Bouvier, Jaime Barnes, Magali Bonifacie, Estelle F. Rose-Koga, Peter Ulmer, Nicole Métrich, Gérard Bardoux, Jeffrey Williams, Graham Layne, et al.

\section{To cite this version:}

Mélina Manzini, Anne-Sophie Bouvier, Jaime Barnes, Magali Bonifacie, Estelle F. Rose-Koga, et al.. SIMS chlorine isotope analyses in melt inclusions from arc settings. Chemical Geology, 2017, 449, pp.112-122. 10.1016/j.chemgeo.2016.12.002 . hal-02109231

\section{HAL Id: hal-02109231 https://hal.uca.fr/hal-02109231}

Submitted on 26 Nov 2020

HAL is a multi-disciplinary open access archive for the deposit and dissemination of scientific research documents, whether they are published or not. The documents may come from teaching and research institutions in France or abroad, or from public or private research centers.
L'archive ouverte pluridisciplinaire HAL, est destinée au dépôt et à la diffusion de documents scientifiques de niveau recherche, publiés ou non, émanant des établissements d'enseignement et de recherche français ou étrangers, des laboratoires publics ou privés. 


\section{Accepted Manuscript}

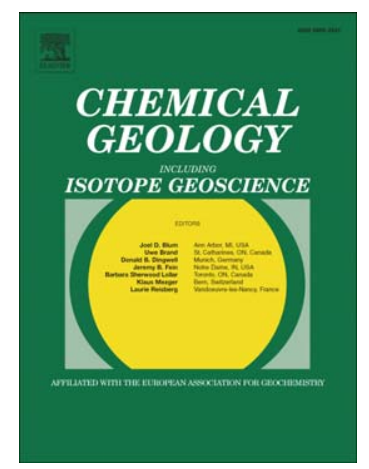

SIMS chlorine isotope analyses in melt inclusions from arc settings

Mélina Manzini, Anne-Sophie Bouvier, Jaime D. Barnes, Magali Bonifacie, Estelle F. Rose-Koga, Peter Ulmer, Nicole Métrich, Gérard Bardoux, Jeffrey Williams, Graham D. Layne, Susanne Straub, Lukas P. Baumgartner, Timm John

PII:

S0009-2541(16)30649-0

DOI: doi: 10.1016/j.chemgeo.2016.12.002

Reference: CHEMGE 18172

To appear in: $\quad$ Chemical Geology

Received date: 5 August 2016

Revised date: 21 November 2016

Accepted date: 2 December 2016

Please cite this article as: Manzini, Mélina, Bouvier, Anne-Sophie, Barnes, Jaime D., Bonifacie, Magali, Rose-Koga, Estelle F., Ulmer, Peter, Métrich, Nicole, Bardoux, Gérard, Williams, Jeffrey, Layne, Graham D., Straub, Susanne, Baumgartner, Lukas P., John, Timm, SIMS chlorine isotope analyses in melt inclusions from arc settings, Chemical Geology (2016), doi:10.1016/j.chemgeo.2016.12.002

This is a PDF file of an unedited manuscript that has been accepted for publication. As a service to our customers we are providing this early version of the manuscript. The manuscript will undergo copyediting, typesetting, and review of the resulting proof before it is published in its final form. Please note that during the production process errors may be discovered which could affect the content, and all legal disclaimers that apply to the journal pertain. 


\title{
SIMS chlorine isotope analyses in melt inclusions from arc settings
}

Mélina Manzini ${ }^{1}$, Anne-Sophie Bouvier ${ }^{1}$, Jaime D. Barnes ${ }^{2}$, Magali Bonifacie ${ }^{3,4}$, Estelle F. Rose-Koga 5 , Peter Ulmer ${ }^{6}$, Nicole Métrich ${ }^{3}$, Gérard Bardoux ${ }^{3}$, Jeffrey Williams ${ }^{7}$, Graham D. Layne ${ }^{8}$, Susanne Straub ${ }^{9}$, Lukas P. Baumgartner ${ }^{1}$, Timm John ${ }^{10}$

1Institute of Earth Sciences, University of Lausanne, 1015 Lausanne, Switzerland

2 Department of Geological Sciences, Jackson School of Geosciences, University of Texas at Austin, Austin, Texas, USA 78712

3 Institut de Physique du Globe de Paris, Sorbonne Paris Cité, Université Paris-Diderot, CNRS UMR 7154, Paris, France

${ }^{4}$ Observatoire Volcanologique et Sismologique de Guadeloupe, Institut de Physique du Globe de Paris, CNRS UMS 3454, Guadeloupe, France

${ }^{5}$ Laboratoire Magmas et Volcans, CNRS, University of Blaise Pascal, Clermont-Ferrand, France ${ }^{6}$ Institute of Geochemistry and Petrology, ETH Zürich, Zürich, Switzerland

7 Dept. Of Earth and Planetary Sciences, University of New Mexico, Albuquerque, USA

${ }^{8}$ Dept. of Earth Sciences, Memorial University, St-John's, NL, Canada

${ }^{9}$ Lamont-Doherty Earth Observatory, Earth Institute, Columbia University, Palisades, USA

10 Institut für Geologische Wissenschaften, Freie Universität Berlin, Germany

Corresponding author: Mélina Manzini, Université de Lausanne, Institut des Sciences de la Terre, Géopolis, CH-1015 Lausanne; melina.manzini@unil.ch

\begin{abstract}
The relative contribution of volatiles from altered oceanic crust, serpentinized mantle, and subducted sediments on the composition of primary arc magmas is poorly constrained. We measured the chlorine stable isotope composition in olivine-hosted melt inclusions in order to provide a first order constraint on the $\delta^{37} \mathrm{Cl}$ values of primary magmas, since melt inclusions are not or only little affected by near surface processes. Chlorine isotope analyses were obtained with a CAMECA IMS 1280-HR at the University of Lausanne. A series of six $\mathrm{Cl}$-bearing glass standards with $\delta^{37} \mathrm{Cl}$ values of -1.1 to $+1.7 \%$, $\mathrm{SiO}_{2}$ between 50 and 76 wt $\%$ and $\mathrm{Cl}$ concentration between 0.15 and 3.25 wt\% were used for
\end{abstract}


calibration. We determined that $\mathrm{SiO}_{2}, \mathrm{Al}_{2} \mathrm{O}_{3}$ and $\mathrm{K}_{2} \mathrm{O}$ in glasses are primarily responsible for the observed variations in instrumental mass fractionation.

We obtained a $\delta^{37} \mathrm{Cl}$ reproducibility on the standard glasses typically better than $0.3 \%$ o (2SD) and a total uncertainty, corresponding to the propagated error of SIMS and PyroIRMS uncertainty, of 0.4\% (2SD). Melt inclusions from Lesser Antilles, Vanuatu and Aeolian arcs display ranges of $\delta^{37} \mathrm{Cl}$ values from -1.9 to $+0.6 \% 0,-1.7$ to $+0.4 \%$ and -3.4 to $-1.4 \%$ respectively. Combined with $\mathrm{Cl} / \mathrm{K}_{2} \mathrm{O}$ ratios, these data suggest that $\mathrm{Cl}$ addition mainly originates from serpentinites (lithospheric serpentinites or serpentinized mantle wedge) in the Lesser Antilles and Vanuatu arcs. In contrast, $\mathrm{Cl}$ added to the mantle wedge beneath the Aeolian Islands may record a higher proportion of fluids derived from the subducting sediments. The observed differences of $\delta^{37} \mathrm{Cl}$ values in melt inclusions from the Lesser Antilles and Vanuatu arcs and the Aeolian Islands may directly reflect the different subduction geometries present.

\section{Keywords}

Chlorine stable isotopes, SIMS, olivine-hosted melt inclusions, volcanic arcs

\section{Introduction}

Chlorine is an important anion in fluids in subduction zone settings (e.g. Stolper and Newman, 1994; Yardley, 1997; Scambelluri and Philippot, 2001; Kent et al., 2002; Manning, 2004). Because of its high solubility in aqueous phases, $\mathrm{Cl}$ content has been previously used as a geochemical tracer of metasomatic processes in the upper crust and mantle (e.g. Barnes et al., 2008, 2009a; Sharp et al., 2010; Rizzo et al., 2013; Li et al., 2015). Stable isotopes of chlorine $\left({ }^{35} \mathrm{Cl}\right.$ and ${ }^{37} \mathrm{Cl}$; natural abundances $75.77 \%$ and $24.23 \%$, respectively) can fractionate during surficial geological processes. However, chlorine isotopes do not fractionate significantly in magmatic regimes (Schauble et al., 2003; John et al., 2010; Halldórsson et al., 2016) and thus the source signature can be retained during dehydration. The limited fractionation of $\mathrm{Cl}$ isotopes during dehydration has been observed in natural samples (Bonifacie et al., 2008a; John et al., 2011; Selverstone and Sharp, 2015). Chlorine isotope ratios could therefore be a potentially powerful tracer of fluid origin in subduction zones (e.g. Barnes et al., 2008, 2009b; Barnes and Straub, 2010; Rizzo et al., 2013; Chiaradia et al., 2014). Moreover, $\delta^{37} \mathrm{Cl}$ studies can provide information on the long-term $\mathrm{Cl}$ cycle from crustal to mantle 
reservoirs and can thus help in understanding the effect of recycling of crustal material on mantle composition (John et al., 2010).

Serpentinites have been proposed to be the main chlorine source into subduction zones (Scambelluri et al., 2004; Barnes and Sharp, 2006; Liebscher et al., 2006; Barnes et al., 2008, 2009b; Barnes and Straub, 2010; Kendrick et al., 2013). Serpentinites may form by seafloor alteration close to ocean ridges, or during bending before entering the subduction zone or, alternatively, in the mantle wedge above subduction zones where dehydrating fluids from the slab ascend into the overlying wedge. Seafloor serpentinites have a near seawater chlorine isotope signature, whereas mantle wedge serpentinites may record the signature of different fluids originating from various crustal lithologies composing the subducting oceanic lithospheric part of the slab (e.g. Barnes and Sharp, 2006; John et al., 2011). A second large reservoir of $\mathrm{Cl}$ is altered oceanic crust (AOC), mostly due to chlorite and amphibole veins created during low to high temperature hydrothermal alteration of the oceanic crust (Ito et al., 1983; Barnes and Cisneros, 2012). This reservoir has been proposed to dominate the $\mathrm{Cl}$ contribution to the mantle wedge and possibly to the $\mathrm{Cl}$ contamination of the deep mantle (e.g. Scambelluri and Philippot, 2001).

Chlorine isotope studies applied to igneous and metamorphic environments are relatively scarce and most of them published since 2005 . These studies mostly use bulk rock analysis. In order to document small-scale $\delta^{37} \mathrm{Cl}$ variations and to analyze material minimally affected by post-magmatic processes, melt inclusions trapped in early-formed minerals were analysed. Melt inclusions are subsequently isolated from the evolving magma and thus represent the composition closest to the primary melt (e.g. Schiano, 2003; Kent, 2008; Métrich and Wallace, 2008). Chlorine concentrations and $\delta^{37} \mathrm{Cl}$ values measured in melt inclusions are representative of the magmatic composition, as $\mathrm{Cl}$ does not diffuse out of the melt inclusion (Le Voyer et al., 2014). Chlorine is degassed from the melt at shallow pressure, well after $\mathrm{H}_{2} \mathrm{O}$ and $\mathrm{CO}_{2}$ (e.g. Spilliaert et al., 2006). Chlorine diffusion from the (quenched) melt into the shrinkage bubble is thus limited. Even if significant amounts of $\mathrm{Cl}$ exsolve into the shrinkage bubble, $\mathrm{Cl}$ isotopes should not fractionate, as no fractionation of $\mathrm{Cl}$ isotopes occurs during degassing at magmatic temperatures (Schauble et al., 2003). Therefore, $\delta^{37} \mathrm{Cl}$ values of melt inclusions in earlyformed olivine in primary or near-primary basalts appears as a potential tool to trace the source of $\mathrm{Cl}$ input into the mantle wedge. To date, only one study has reported $\delta^{37} \mathrm{Cl}$ 
values in olivine-hosted melt inclusions (Layne et al. 2009). The composition range from $-4.0 \pm 1.4$ to $+1.5 \pm 0.8 \%(2 \sigma)$ for 24 melt inclusions from the Lau back-arc basin. These values span the range of $\delta^{37} \mathrm{Cl}$ values of most terrestrial rocks (Figure 1). This large variation has been attributed to the influence of several sources (combination of AOC, serpentinites and an unidentified reservoir with low $\delta^{37} \mathrm{Cl}$ values).

Because melt inclusions are typically smaller than $200 \mu \mathrm{m}$ (mostly in the range 40-100 $\mu \mathrm{m})$, their chlorine isotope composition requires an in-situ technique. Furthermore, the narrow range of a few per mil variation in $\delta^{37} \mathrm{Cl}$ values observed for natural magmas on Earth requires adequate analytical precision. Godon et al. (2004c) and Layne et al. (2004) developed a method for $\delta^{37} \mathrm{Cl}$ determination of glasses using a Cameca IMS 1280 ion probe and a single electron multiplier (EM) as detectors for ${ }^{35} \mathrm{Cl}$ and ${ }^{37} \mathrm{Cl}$. Layne et al (2009) and John et al. (2010) improved on this method, using EM multicollection (Cameca IMS 1270), and achieved internal precisions for the determination of $\delta^{37} \mathrm{Cl}$ in basaltic glasses of routinely better than $0.6 \% 0-1.0 \% 0(2 \sigma)$. As stated by Layne et al. (2009), there is a need for improving both accuracy and precision for Secondary Ion Mass Spectrometer (SIMS) determination, especially in samples with low $\mathrm{Cl}$ contents $(<$ $300 \mathrm{ppm}$ ). The significant instrumental mass fractionation (IMF) that occurs during SIMS analysis requires correction using appropriate reference materials. IMF depends on the structure and on the composition of the analysed material (Shimizu and Hart, 1982; Eiler et al., 1997), which influence the sputtering and ionization rate (Sigmund, 1969; Schroeer et al., 1973; Williams, 1979; Yu and Lang, 1986), as well as the energy bandwidth of the secondary ion transmission (Shimizu and Hart, 1982), and physical and electronic effects within the detection system (Valley and Graham, 1991; Lyon et al., 1994). These latter two processes do not vary appreciably from one sample to another for glasses. However, compositional variations within glasses have an appreciable effect on the IMF for $\delta^{37} \mathrm{Cl}$ determination. A set of glass standards, homogenous in major elements, $\mathrm{Cl}$ concentrations and in $\delta^{37} \mathrm{Cl}$ compositions, and covering an appropriate range of major element compositions, is thus required. $\mathrm{Cl}$ concentrations of the glass standards should also be relatively similar to the analysed samples allowing analysis of both standards and unknown samples with identical setup conditions (i.e. same primary current and detectors). For natural glasses, Godon et al. (2004c) inferred that almost $85 \%$ of the IMF can be explained by the $\mathrm{SiO}_{2}$ and $\mathrm{Al}_{2} \mathrm{O}_{3}$ compositional variations alone ( $\mathrm{Si}$ and $\mathrm{Al}$ are network forming cations) and that $\mathrm{FeO}$ and $\mathrm{CaO}$ concentrations ( $\mathrm{Fe}$ and $\mathrm{Ca}$ 
are network modifiers) will also modify the IMF to a lesser extent. They thus suggested an IMF correction based on these 4 elements.

In the present study we propose a setup for in-situ high-precision chlorine isotope analyses with SIMS, specifically for high $\mathrm{Cl}$ content glasses (> $900 \mathrm{ppm}$ ). This setup involves the use of two Faraday Cups (FC) as detectors instead of an electron multiplier, resulting in better precision and a slightly different IMF correction scheme compared to the one proposed by Godon et al. (2004c) and Layne et al. (2004). We applied this calibration to a set of olivine-hosted melt inclusions from Aeolian, Vanuatu and Lesser Antilles volcanic arcs to expand the database for $\delta^{37} \mathrm{Cl}$ data set in melt inclusions. This increases our understanding of the small-scale variability of $\delta^{37} \mathrm{Cl}$ and the $\mathrm{Cl}$ cycle in subduction related crust-mantle systems.

\section{Sample description and geological context}

Olivine-hosted melt inclusions from Vulcano and Stromboli (Aeolian Islands), Aoba (Vanuatu arc) and St-Vincent (Lesser Antilles arc) island-arc systems were selected for this project. The selected olivines are euhedral and melt inclusions are crack-free.

All studied melt inclusions are larger than $30 \mu \mathrm{m}$ and hosted in olivines from lapilli deposits. They are from already well-characterized rock samples with respect to their chemical composition and geological contexts, thereby facilitating the interpretation of the first $\delta^{37} \mathrm{Cl}$ data obtained from melt inclusions from island arc volcanoes. All studied melt inclusions $(n=48)$ are glassy, and most of them $(>70 \%)$ contained a shrinkage bubble.

The magma compositions of the Aeolian arc volcanoes were suggested to record the melting of a MORB-OIB-like mantle component and subsequent metasomatism by fluids from the Ionian oceanic crust and the abundant sediments from the Ionian basin in the eastern part of the arc (Peccerillo et al., 2013 and references therein). Olivine-hosted melt inclusions from Stromboli are from the lower and middle Vancori unit. Melt inclusions from Vulcano are from the La Sommata scoria cone.

Aoba (Vanuatu arc) lava and melt inclusion geochemistry is described in Sorbadere et al. (2011). Samples are from three different locations: Ao3 from a north flank fissure, Ao15 from the Torgil tuff ring and Ao17 from the Red Cliff pyroclastic sequence. The parental magma is generated by partial melting of a metasomatized peridotitic mantle wedge (Eggins, 1993; Raos and Crawford, 2004; Sorbadere et al., 2011). Subducted sediments 
in the Vanuatu trench are dominantly volcanoclastics (Peate et al., 1997). The presence of slab-derived fluids, possibly involving serpentinites, has been proposed by Métrich and Deloule (2014), based on boron isotopes $\left(\delta^{11} \mathrm{~B}\right)$.

The geological context of St-Vincent and the geochemistry of melt inclusions are described in several publications (e.g. Bouvier et al., 2008, 2010). Olivine-hosted melt inclusions used for this study (SVN4b) come from lapilli deposits on the west coast of StVincent, near Troumaka beach (Bouvier et al., 2008). Basaltic to picritic melts from StVincent result from partial melting of a (MORB) mantle source that experienced multistage metasomatic events. These include a seawater-derived fluid event, possibly produced during serpentinite dehydration. A subsequent event involved fluids derived from the dehydration of AOC and subducted sediments (Bouvier et al., 2010), possibly terrigenous and related to a large accretionary prism (Westbrook, 1975; White and Patchett, 1984; Davidson, 1985; White and Dupré, 1986; Turner et al., 1996; Macdonald et al., 2000; Carpentier et al., 2008).

\section{Methodology}

To determine the IMF calibration line, 6 different glass standards with $\mathrm{Cl}$ concentration ranging between 0.15 and $3.25 \mathrm{wt} \% \mathrm{Cl}$ and covering a wide range of major element compositions were used. Three of them were synthetised for this study. In addition to these synthetic glasses, one natural rhyolite obsidian, RMR (Godon et al., 2004c), one natural pantellerite (PR2) and one natural basaltic glass from Izu Bonin, IB94 (Barnes and Straub, 2010) were used. Compositions are listed in Table 1.

\subsection{Standard glass synthesis}

The glass standards were synthetized using a piston cylinder apparatus at ETH Zürich, Switzerland. This technique was chosen in order to obtain high $\mathrm{Cl}$ content, similar to the least degassed MIs from arc settings. Similar $\mathrm{Cl}$ content in synthetic glasses and MIs allow us to optimize the SIMS analytical conditions for a better precision. Because of the low quantity of glass synthesized in a high-pressure piston cylinder apparatus and the comparatively large amount required for subsequent bulk $\delta^{37} \mathrm{Cl}$ analysis, a total of $2 \mathrm{~g}$ of starting material (mixed silicate powder and $\mathrm{NaCl}$ ) was prepared, allowing for to conduct of several experiments with the same glass composition (e.g., 7 runs for UNIL_GL-B6). 
Synthetic mixtures of Cl-enriched basaltic compositions were prepared from high-purity and reagent grade oxide $\left(\mathrm{SiO}_{2}, \mathrm{TiO}_{2}, \mathrm{Al}_{2} \mathrm{O}_{3}, \mathrm{Fe}_{2} \mathrm{O}_{3}, \mathrm{MgO}\right)$ and silicate $\left(\mathrm{CaSiO}_{3}, \mathrm{Na}_{2} \mathrm{SiO}_{3}, \mathrm{~K}-\right.$ silicate $\left(\mathrm{SiO}_{2}: \mathrm{K}_{2} \mathrm{O}\right.$ 2.5:1) powders. $\mathrm{NaCl}$ was used as a source for $\mathrm{Cl}$ (concentration and isotopes; Merck, Suprapur, Lot\# B732806543). The compositions of $\mathrm{CaSiO}_{3}, \mathrm{Na}_{2} \mathrm{SiO}_{3}$ and K-silicate were determined by XRF analyses beforehand to determine their exact stoichiometry and check for impurities. Corresponding weights for the final composition were adjusted accordingly. Oxides and silicates were either fired $\left(\mathrm{SiO}_{2}, \mathrm{TiO}_{2}, \mathrm{Fe}_{2} \mathrm{O}_{3}, \mathrm{MgO}\right.$, $\left.\mathrm{CaSiO}_{3}\right)$ at $1000^{\circ} \mathrm{C}$ in Pt-crucibles in a furnace or dried at $220^{\circ} \mathrm{C}$ in an oven $\left(\gamma-\mathrm{Al}_{2} \mathrm{O}_{3}\right.$, $\mathrm{Na}_{2} \mathrm{SiO}_{3}, \mathrm{~K}$-silicate, $\mathrm{NaCl}$ ) prior to weighing the individual components in appropriate proportions to obtain 2 grams of the desired basalt compositions. All powder mixtures were dried and stored at $220^{\circ} \mathrm{C}$ in an oven to minimize adsorption of water. All starting mixture only contained ferric iron added as $\mathrm{Fe}_{2} \mathrm{O}_{3}$ in order to prevent $\mathrm{Fe}$-loss to the Ptcapsules employed during high-pressure, high-temperature synthesis.

Aliquots of 120 - $170 \mathrm{mg}$ of the individual powders were tightly packed into preannealed $4 \mathrm{~mm}$ OD Pt capsules that were welded shut with a tungsten arc welder and further compacted in a dye to total lengths of $8.6-10.0 \mathrm{~mm}$. All synthesis experiments were run in end-loaded, solid media, high-pressure piston cylinder apparatus with 14 $\mathrm{mm}$ piston diameter. At temperatures below $1450^{\circ} \mathrm{C}$, assemblies consisted of talc-Pyrexgraphite-MgO parts, temperature was recorded and controlled with B-type $\left(\mathrm{Pt}_{70} \mathrm{Rh}_{30}-\right.$ $\mathrm{Pt}_{94} \mathrm{Rh}_{6}$ ) thermocouples contained in mullite sleeves protected by a $0.6 \mathrm{~mm}$ thick corundum disc from the capsule. At higher temperatures, Pyrex glass was replaced by silica glass and the thermocouples were contained in $\mathrm{Al}_{2} \mathrm{O}_{3}$ sleeves. All experiments were conducted at 0.7 or $0.8 \mathrm{GPa}$ (Table 2). Runs lasted for 60 to 150 minutes and were terminated by shutting of the furnace power resulting in near-isobaric quenching with rates exceeding $100^{\circ} \mathrm{C} / \mathrm{sec}$ down to $300^{\circ} \mathrm{C}$ and slower cooling below. Temperature gradients along the capsules should not have exceeded $22{ }^{\circ} \mathrm{C}$ according to numerical modeling based on the Hernlund et al. (2006) algorithm. Capsules were centered in the hotspot; therefore, temperatures recorded by the thermocouple and listed in Table 2 are minimum temperatures that were exceeded by $13-22{ }^{\circ} \mathrm{C}$ in the center of the capsules. Recovered charges were carefully cleaned for adhering MgO powders using a diamond file prior to opening and extracting the glass.

\subsection{Sample preparation}


The synthesized glasses were crushed into small pieces $(100-800 \mu \mathrm{m})$. Representative glass chips from each run were embedded into a single 1-inch epoxy mount and polished for EMPA and SIMS analyses.

Olivine crystals from crushed scoriae were hand-picked under a binocular microscope and embedded in epoxy resin. Crystals were then individually polished in order to expose the melt inclusions at the surface. Once the melt inclusions were exposed, the selected olivines were removed from the epoxy and pressed into 1-inch high-purity (99.99\%) indium mounts. Polished chips of the three synthetic $\delta^{37} \mathrm{Cl}$ glass standards (UNIL_GL-B4, UNIL_GL-B6, and UNIL_GL-B7) were also pressed into each mount.

\subsection{Chemical and isotopic characterization}

\subsubsection{Electron microprobe}

Major element compositions of the new glass standards (UNIL-Gl_B4, UNIL-Gl_B6 and UNIL-Gl_B7) and melt inclusions were determined by electron microprobe (EMPA) using a JEOL 8200 Superprobe at University of Lausanne. Analytical conditions were $15 \mathrm{kV}$ acceleration voltage, $10 \mathrm{nA}$ beam current and a beam size of $10 \mu \mathrm{m}$. Counting time was $30 \mathrm{sec}$ on all elements, except for $\mathrm{K}(20 \mathrm{sec}), \mathrm{Na}(16 \mathrm{sec})$ and $\mathrm{Cl}(40 \mathrm{sec})$. A glass standard (KL2-G, Jochum et al., 2006) was used to calibrate $\mathrm{SiO}_{2}$ and $\mathrm{Al}_{2} \mathrm{O}_{3}$. Other elements were calibrated on a variety of silicates, oxides and metals. ML3B-G (Jochum et al., 2006) was used as an internal glass standard. At least 4 points within each glass chip and olivine and 2 points within each melt inclusions were obtained. Uncertainties, given as $1 \sigma$, are is typically $<1 \%$ for $\mathrm{SiO}_{2}, \mathrm{Al}_{2} \mathrm{O}_{3}, \mathrm{MgO}, \mathrm{CaO}, \mathrm{FeO}, \mathrm{K}_{2} \mathrm{O},<2 \%$ for $\mathrm{Na}_{2} \mathrm{O},<4 \%$ for $\mathrm{TiO}_{2}$ and $<20 \%$ for $\mathrm{MnO}$.

Major elements and $\mathrm{Cl}$ concentration of the chlorine isotope standards were verified using an EMPA at Laboratoire Magmas et Volcans (LMV; University Blaise Pascal of Clermont-Ferrand). Major elements of some Aeolian melt inclusions were also determined in this laboratory. Analytical conditions are described in Rose-Koga et al. (2012).

Olivine post-entrapment crystallization (PEC \%, Table 3) at the wall of melt inclusion was estimated using the Petrolog software (Danyushevsky et al., 2000, 2002; Danyushevsky and Plechov, 2011).

\subsubsection{Raman}


Water concentrations of the glasses were determined by Raman spectroscopy at LMV, Clermont-Ferrand using a Renishaw InVia spectrometer equipped with a high sensitivity ultra-low noise RenCam CCD detector. The laser set at a wavelength of $532 \mathrm{~nm}$, was used to excite Raman scattering. Final spectra represent the average of two spectra with an acquisition time between $10 \mathrm{sec}$ to $120 \mathrm{sec}$ for shifts relative to the laser light wavelength ranging between 500 to 2,000 $\mathrm{cm}^{-1}$ (aluminosilicate framework domain, TOT) and 3,200 to 3,800 $\mathrm{cm}^{-1}$ (OH stretching domain). The precision calculated on four of the five basaltic standards $\left(\mathrm{H}_{2} \mathrm{O}>1 \mathrm{wt} \%\right)$ is better than $2 \% 2 \mathrm{SD}$ in condition of standard confocality. The precision calculated on the fifth basaltic standard $(0.5 \mathrm{wt} \%$ $\mathrm{H}_{2} \mathrm{O}$ ) is around $5 \% 2 \mathrm{SD}$.

\subsubsection{Pyrohydrolysis-IRMS measurements of $\delta^{37} \mathrm{Cl}$}

The chlorine isotope ratios of the first set of synthetized glasses, as well as the natural glasses RMR, PR2, and IB94, were measured at the Department of Earth and Planetary Sciences at the UNM (University of New Mexico Albuquerque) using continuous flow measurements on a Finnigan MAT Delta Plus XL. The second set of synthetized glasses was analysed at the Institut de Physique du Globe de Paris (IPGP) using the dual-inlet mode on a Thermo Fisher Scientific Delta V mass spectrometer. Measurements of $\delta^{37} \mathrm{Cl}$ compositions by dual-inlet requires more material (minimum of few hundreds of $\mu \mathrm{g} \mathrm{Cl}$ ) than those performed with continuous-flow spectrometers $(50 \mu \mathrm{g} \mathrm{Cl})$. Natural glasses RMR and PR2 were also analysed at the University of Texas at Austin in continuous flow using a ThermoElectron MAT 253. Long-term external reproducibility on replicate $\delta^{37} \mathrm{Cl}$ measurements of seawater reference materials is typically better than $\pm 0.2 \%$ (2SD) in dual-inlet mode (Godon et al., 2004b; Bonifacie et al., 2007a; Giunta et al., 2015; Li et al., 2015 ), $\pm 0.7 \%$ (2SD) in continuous flow at UNM (Sharp et al., 2013), and $\pm 0.4 \%$ (2SD) in continuous flow at UT-Austin (e.g., Chiaradia et al., 2014). Larger long-term external reproducibilities for silicate reference materials are, de facto, obtained in respective laboratories (because $\delta^{37} \mathrm{Cl}$ analyses of silicates requires a prior step of extraction of chlorine from the silicate network, for example here by pyrohydrolysis in both laboratories). Long-term external reproducibility for silicate reference materials are typically \pm 0.28\%o (2SD; $n=15$ ) in IPGP for Andesite S0100DS92 (Bonifacie et al., 2007a, 2008a). In this study, Andesite S0100DS92 yielded a reproducibility of $\pm 0.18 \%$ (2SD, $n$ =4). At both UNM and UT-Austin the same serpentinite rock standard (EL05-13) is used 
with a reproducibility of $\pm 0.8 \%$ (2SD) at UNM (Selverstone and Sharp, 2013) and \pm 0.4\%o (2SD) at UT-Austin (e.g. Barnes and Cisneros, 2012; Chiaradia et al., 2014).

In all three laboratories, chlorine from silicates is extracted by pyrohydrolysis with, however, slight differences between the laboratories (see detailed description of IPGP's method in Bonifacie et al. (2007b); and of UNM's and UT-Austin's method in Sharp et al. (2007) and Selverstone and Sharp (2013). All laboratories convert the aqueous Clbearing solution to gaseous methyl chloride $\mathrm{CH}_{3} \mathrm{Cl}$ (chlorides are first precipitated as $\mathrm{AgCl}$ via reaction with $\mathrm{AgNO}_{3}, \mathrm{AgCl}$ is then converted to $\mathrm{CH}_{3} \mathrm{Cl}$ by reaction with $\mathrm{CH}_{3} \mathrm{I}$ at $80^{\circ} \mathrm{C}$, followed by gas chromatography purification from excess $\mathrm{CH}_{3} \mathrm{I}$ ) as recommended by Eggenkamp (1994) with only slight modifications (see Godon et al. (2004b) and Barnes and Sharp (2006) for more details).

\subsection{SIMS measurements}

Chlorine isotope ratios $\left(\delta^{37} \mathrm{Cl}\right)$ were determined using a CAMECA ims1280-HR Secondary Ion Mass Spectrometer at the SwissSIMS laboratory (University of Lausanne). Samples were sputtered with a 1.5-2 $\mathrm{nA} \mathrm{Cs}^{+}$primary beam accelerated through a nominal potential of $10 \mathrm{kV}$. In order to remove all possible $\mathrm{Cl}$ contamination from the sample surface, a pre-sputtering of $240 \mathrm{sec}$ with a $25 \mu \mathrm{m}$ raster applied to the beam was employed. Analysis time was $240 \mathrm{sec}$ with a $10 \mu \mathrm{m}$ raster applied to the beam. Spot crater diameter at the end of analysis was typically $15 \mu \mathrm{m}-12 \mu \mathrm{m}$. The total time for each analysis, including pre-sputtering and automated centering of the secondary beam in field and contrast apertures, was nearly 10 minutes. Secondary ions were extracted into the mass spectrometer through a potential of $10 \mathrm{kV}$ and selected through an electrostatic field. The energy slit of the mass spectrometer was set to $50 \mathrm{eV}$ width. ${ }^{35} \mathrm{Cl}^{-}$ and ${ }^{37} \mathrm{Cl}^{-}$were measured simultaneously on two separate Faraday Cup on L'2 and H'2 detectors using $10^{11} \mathrm{ohms}$ resistors. Mass resolving power (MRP) was set to $\sim 3000$. Theoretically, this MRP does not produce full separation of ${ }^{35} \mathrm{Cl}^{-}$from ${ }^{34} \mathrm{~S}^{1} \mathrm{H}$ peaks. However, due to the extremely high ratio of $\mathrm{Cl} / \mathrm{S}$ in these materials, the relative isotopic abundances of ${ }^{34} \mathrm{~S}(4.25 \%$ of $\mathrm{S})$ and ${ }^{35} \mathrm{Cl}^{-}(75.28 \%$ of $\mathrm{Cl})$ and the fact that ${ }^{34} \mathrm{~S}^{1} \mathrm{H}$ is polyatomic species with consequently lower ionization probability than $\mathrm{Cl}^{-}$, the contribution of ${ }^{34} \mathrm{~S}^{1} \mathrm{H}$ to secondary ion signal should be negligible for this determination (Godon et al., 2004c). Based on mass scans, with this FC-FC setup, ${ }^{34} \mathrm{~S}^{1} \mathrm{H}$ did not appear 
at MRP 5000 or 3000 , implying that the count rate on the interference is below the FC detection limit due to baseline noise $\left(<\sim 10^{4} \mathrm{cps}\right)$. We thus choose to work with MRP of 3000 in order to obtain a higher count rate for a better measurement precision. The intensity of the secondary ions was $\sim 1600 \mathrm{cps} / \mathrm{ppm} \mathrm{Cl} / \mathrm{nA}$ for ${ }^{35} \mathrm{Cl}$ and $\sim 550 \mathrm{cps} / \mathrm{ppm}$ $\mathrm{Cl} / \mathrm{nA}$ for ${ }^{37} \mathrm{Cl}$. 24 counting cycles of 8 sec each were collected for each analysis. The measurement error (also called internal error), based on the standard error of the mean

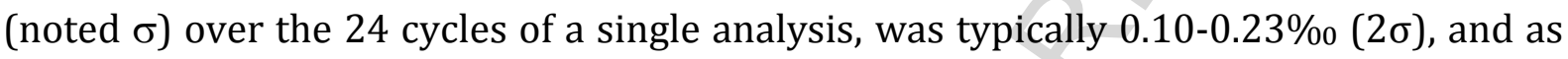
low as $0.03 \%$, $(2 \sigma)$ for the $3 \mathrm{wt} \% \mathrm{Cl}$ glass. Additional analytical parameters are summarized in the Table 4.

SIMS $\delta^{37} \mathrm{Cl}$ measurements were made during four sessions. Sessions 1 and 2 were dedicated to measuring the reproducibility of $\delta^{37} \mathrm{Cl}$ analyses on the new glass standards (UNIL_GL-B4, UNIL_GL-B6 and UNIL_GL-B7) and sessions 3 and 4 to analyze the 6 glass standards to determine the IMF calibration scheme. Melt inclusions were analysed during session 4. Typically, measurement reproducibility (also called external error, noted 2SD (SD for standard deviation)) of the UNIL_GL-B7 standard over 8 hours is $<0.15 \%$ o (2SD).

\section{Results}

\subsection{New synthetic glass standards}

Two of the new synthetic glasses (UNIL_GL-B6 and UNIL_GL-B7) are completely glassy whereas the third one (UNIL_GL-B4) contains quench nanocrystals with a size of $\sim 50$ $\mathrm{nm}$. This glass was included in the analysis to test if the presence of those nanocrystals affects the IMF.

The homogeneity of the synthetic glass standards was tested within each glass chip and between all the experimental glasses fabricated during several experimental runs with the same starting material. All synthetized glasses, even UNIL_Gl-B4 containing quench crystals, are homogenous in major element composition (e.g. $<2 \%$ variation for $\mathrm{SiO}_{2}$, $\mathrm{Al}_{2} \mathrm{O}_{3}, \mathrm{FeO}, \mathrm{MgO}, \mathrm{CaO}$ and $<5 \%$ for $\mathrm{Cl}, \mathrm{K}_{2} \mathrm{O}$ and $\mathrm{Na}_{2} \mathrm{O}$ ), and retain a composition close to the nominal starting material concentrations for major elements. The exception is $\mathrm{Cl}$ which generally exceeds the nominal value by about $10-20 \%$, but remains within the weighing error (typically $\pm 1 \mathrm{mg}$ ) and that of the EMPA (generally $<5 \%, 1 \mathrm{SD}$ ). Measured concentration of $\mathrm{FeO}$, when stochiometrically converted to $\mathrm{Fe}_{2} \mathrm{O}_{3}$, is within the error of the nominal starting compositions, demonstrating that the use of fully oxidized starting 
materials successfully prevented any significant Fe-loss to the Pt-capsules. No compositional difference was observed between the glasses produced in different runs from a given starting material.

Chlorine stable isotope compositions $\left(\delta^{37} \mathrm{Cl}\right)$ are expressed as $\left({ }^{37 / 35} \mathrm{Cl}\right)_{\text {Unknown }}$ $\left.(37 / 35 \mathrm{Cl})_{\text {SMOC }} /-1 * 1000\right]$ in per mil notation relative to standard mean oceanic chloride (SMOC, ${ }^{37 / 35} \mathrm{Cl}=0.324$; Kaufmann et al., 1984). Chlorine isotope ratios of the glasses (except for UNIL_GL-B4 which was analysed only at University of New Mexico (UNM) and of the reagent $\mathrm{NaCl}$ used to dope the experiments was determined in two laboratories (Institut de Physique du Globe Paris (IPGP) and UNM), with two different mass spectrometric methods for isotope measurements (ie., dual-inlet and continuous flow, respectively). Similar results were obtained, with $\delta^{37} \mathrm{Cl}$ within the uncertainty reported for each laboratory (Table 1). Chlorine isotope ratio of the $\mathrm{NaCl}$ determined in IPGP laboratory is $-0.12 \pm 0.18 \%$ o (2SD, $n=8)$ and in UNM laboratory $\delta^{37} \mathrm{Cl}=-0.20 \pm$ $0.03 \%$ (2SD, $\mathrm{n}=2$ ). We average the $\delta^{37} \mathrm{Cl}$ values from both laboratories and determined a $\delta^{37} \mathrm{Cl}$ value for the $\mathrm{NaCl}$ used to dope the experiments of $-0.14 \pm 0.18 \%$ (2SD; $\mathrm{n}=10$ ). The $\delta^{37} \mathrm{Cl}$ of glasses analysed in both laboratories was calculated by averaging of all measured values and is referred as " ${ }^{37} \mathrm{Cl}$ accepted values" in Table 1.

UNIL_GL-B4 and UNIL_GL-B7 have $\delta^{37} \mathrm{Cl}$ compositions similar to the reagent $\mathrm{NaCl}$ used to dope the synthetized glasses (UNIL_GL-B4, UNIL_GL-B6 and UNIL_GL-B7) with Cl, indicating that no fractionation occurred during the synthesis, despite the presence of quench nanocrystals in UNIL_GL-B4. However, UNIL_GL-B6 has a $\delta^{37} \mathrm{Cl}$ composition significantly different from the reagent $\mathrm{NaCl}(1.77 \pm 0.20 \%$ o (2SD) versus $-0.14 \pm 0.18$ (2SD)). Possible explanations for this difference are discussed below.

Glass chips from each individual run of every standard were analysed with more than 4 in situ analyses per chip in order to test the microscale $\delta^{37} \mathrm{Cl}$ homogeneity. The chips from different runs for a given standard have similar $\delta^{37} \mathrm{Cl}$ values (with a reproducibility of 0.12 to $0.31 \%$ (2SD), similar to the reproducibility on glass chips from a single run), indicating that for all glasses obtained by experimental synthesis in this study, no chlorine isotopic fractionation occurs during the glass synthesis (Figure 2).

These 3 new synthetic glasses are highly homogeneous (reproducibility $\leq 0.31 \%$ for each glass standard in all the sessions) in $\delta^{37} \mathrm{Cl}$ at scale down to $30 \mu \mathrm{m}$ (Table 1 and 5). For comparison, the pantellerite glass standard PR2 (Table 1) is also highly reproducible $(<0.25 \%$, 2SD, n=6), whereas RMR (Godon et al., 2004c and Table 1) and IB94 (Barnes 
and Straub, 2010) are slightly less homogenous, with a reproducibility of 0.73 (2SD, $\mathrm{n}=6)$ and 0.52 (2SD, $\mathrm{n}=6$ ) respectively. RMR has a slightly better uncertainty of bulk data $(0.60,2 S D)$ compared to SIMS data $(0.79,2 S D)$, indicating a small-scale heterogeneity of this glass, at least in some pieces. IB94 contains a few small crystals of plagioclase and pyroxene that were avoided during analysis.

The total uncertainty reported for the IMF corresponds to the propagation of the reproducibility of SIMS $\left(2 \sigma_{\text {SIMS }}\right)$ and Pyro-IRMS $\left(2 \sigma_{I R M S}\right)$ analyses $(2 \sigma)$ is generally better than $0.4 \%$ o $(2 \mathrm{SD})$.

$$
\text { Total uncertainty }(2 \sigma)=\sqrt{\left(2 \sigma_{S I M S}\right)^{2}+\left(2 \sigma_{I R M S}\right)^{2}}
$$

Reproducibility and total uncertainties for $\delta^{37} \mathrm{Cl}$ determination for the different glasses are summarized in Tables 1 and 5.

\subsection{Olivine hosted melt inclusions}

Melt inclusions are hosted in $\mathrm{Fo}_{68-89}$ olivines. They have a $\mathrm{Cl}$ concentration ranging between 900 and 4600 ppm (except for one melt inclusion with 660 ppm). This allows measurements with the same analytical setup as the set of glass standards. Melt inclusions from the 4 samples analysed in this study have $\delta^{37} \mathrm{Cl}$ values ranging from $3.4 \pm 0.2 \%$ to $+0.6 \pm 0.3 \%$ o $(2 \sigma)$ (Table 3 ). Melt inclusion compositions are reported in Table 3. Melt inclusions from St-Vincent $(n=17)$ and Aoba $(n=17)$ have 2.5\%o variations in $\delta^{37} \mathrm{Cl}$ values for different $\mathrm{Cl}$ contents of St-Vincent (800-1300 ppm Cl for St-Vincent; $1900-3900$ ppm for Aoba, except for one melt inclusion with 660 ppm). In contrast, melt inclusions from La Sommata $(\mathrm{n}=7)$ have only $1.4 \%$ variations for $\mathrm{Cl}$ contents ranging from 3300 to $4400 \mathrm{ppm}$. Stromboli melt inclusions $(\mathrm{n}=5)$ have $1.8 \%$ variations in $\delta^{37} \mathrm{Cl}$ and a $\mathrm{Cl}$ concentration of $1200-1800 \mathrm{ppm}$. The range in $\delta^{37} \mathrm{Cl}$ in melt inclusions is not related to the $\mathrm{Cl}$ concentration (i.e., Aeolian melt inclusions have higher $\mathrm{Cl}$ concentration but still a large $\delta^{37} \mathrm{Cl}$ variation), indicating that the $\delta^{37} \mathrm{Cl}$ variation is not a signal dependent analytical artifact. Inclusions with $\mathrm{Cl}$ concentration in excess of $2000 \mathrm{ppm}$ result in a measurement error $<0.25 \%$ o $(2 \sigma)$ and no correlation between the $\mathrm{Cl}$ content and measurement error can be observed (Figure 3). Below $2000 \mathrm{ppm} \mathrm{Cl}$, the measurement error clearly increases as $\mathrm{Cl}$ concentration decreases and is typically 0.30 $0.35 \%$ o $(2 \sigma)$ for $\mathrm{Cl}$ concentration of $1300 \mathrm{ppm}, 0.40-0.50 \%$ o $(2 \sigma)$ for $1000 \mathrm{ppm}$ and $0.75 \%$ 
$(2 \sigma)$ for $660 \mathrm{ppm}$; in any case lower than the isotopic variability observed for the melt inclusions samples.

\section{Discussion}

\subsection{Chlorine isotope ratio of glass standards}

In most experiments, $\delta^{37} \mathrm{Cl}$ of the synthetized glass was the same as the $\delta^{37} \mathrm{Cl}$ of the $\mathrm{NaCl}$ used in the starting material. However, UNIL_GL-B6 glass has a strongly different $\delta^{37} \mathrm{Cl}$ composition ( $1.77 \pm 0.20 \%$ ) compared to the $\mathrm{NaCl}$ source used in the starting material ($0.14 \pm 0.18 \%$ ) is not likely the result of fractionation during synthesis since 1 ) the SIMS analyses of different runs (UNIL_GL-B6 run\#0 to UNIL_GL-B6 run\#6) result in the same $\delta^{37} \mathrm{Cl}$ (Figure 2, Table 5), and 2) the measured $\mathrm{Cl}$ concentrations after synthesis correspond, within the analytical and weighting error, to the added $\mathrm{Cl}$ content. Moreover, $\delta^{37} \mathrm{Cl}$ does not fractionate at high temperature (Schauble et al., 2003), as experimentally confirmed during glass synthesis at temperatures exceeding $1000^{\circ} \mathrm{C}$ (Godon et al., 2004b; Sharp et al., 2013). It is thus probable that fractionation of $\mathrm{Cl}$ isotopes occurred during powder preparation, even if the process leading to this fractionation remains unclear.

\subsection{Instrumental mass fractionation}

The IMF varies from 5 to $9 \%$ within the set of standards used and which cover a large range of major element compositions (Table 1). Even though no single element can explain the IMF (Figure 4) alone, it is clear that some elements are correlated with the IMF. A combination of several elements needs to be used to quantify IMF. The contribution of the different elements was determined using a least square regression procedure (Bevington and Robinson, 2002). $\mathrm{Al}_{2} \mathrm{O}_{3}, \mathrm{SiO}_{2}$ and $\mathrm{K}_{2} \mathrm{O}$ result in the best IMF correction fit for SIMS analyses of glasses (Figure 5). Quality of the fit, given as $\chi^{2}$ per point, is smaller than 0.25 in Figure 3. A $\chi^{2}$ per point of 1 is considered as a good fit. Values smaller than 1 indicate that the errors are overestimated. The obtained calibration line has a $\mathrm{R}^{2}>0.99$ (Figure 5). The error related to the fitting of the calibration equation is thus subsidiary, with the accuracy of IMF correction depending mainly on SIMS and bulk measurements uncertainty.

Using physical properties, such as density, does not improve the IMF correction. Major element composition controls some of the glass properties, such as the degree of melt 
polymerization $(\mathrm{NBO} / \mathrm{T})$ or optical basicity, both of which depend on the concentration of different types of bridging oxygen (Mysen et al., 1985; Duffy, 1993) and which has an effect on the sputtering rate during analysis. However, even if IMF is strongly controlled by $\mathrm{Al}_{2} \mathrm{O}_{3}$ and $\mathrm{SiO}_{2}$, which are also controlling the degree of melt polymerization (Mysen, 1990) no correlation between NBO/T or optical basicity and IMF were found. The amount of $\mathrm{H}_{2} \mathrm{O}$ or $\mathrm{Cl}$ are poorly correlated to the IMF, suggesting that these 2 elements are not influencing the IMF. Using IMF correction based on $\mathrm{Al}_{2} \mathrm{O}_{3}, \mathrm{SiO}_{2}$ and $\mathrm{K}_{2} \mathrm{O}$ is thus sufficient to correct for the IMF.

\subsection{Chlorine isotope ratios of melt inclusions}

The presented dataset, reporting the first $\delta^{37} \mathrm{Cl}$ analyses of melt inclusion from various island-arc settings, reveal $\delta^{37} \mathrm{Cl}$ values between $-3.4 \pm 0.2$ and $0.6 \pm 0.3 \%$ o $(2 \sigma)$, a range encompassing the range of most terrestrial rocks (Figure 1), and similar to the range of $\delta^{37} \mathrm{Cl}$ reported for Lau Basin melt inclusions (Layne et al., 2009). The melt inclusions from this study originate from basaltic rocks generated in subduction zones settings. They are thus enriched in chlorine compared to basalts generated from other mantle domains, such as N-type MORB representing partial melts from depleted asthenospheric mantle. One or more additional sources of $\mathrm{Cl}$ are thus required to account for the $\mathrm{Cl}$ isotope compositions recorded by the melt inclusions. Several studies have shown that slab lithologies keep their initial $\delta^{37} \mathrm{Cl}$ during metamorphic devolatilization and partial melting (e.g. Barnes and Sharp, 2006; Bonifacie et al., 2008a; John et al., 2011; Selverstone and Sharp, 2013). The $\delta^{37} \mathrm{Cl}$ signature of the fluids and hydrous melts escaping from a certain subducted lithology should thus have a $\delta^{37} \mathrm{Cl}$ composition similar to this specific lithology. The isotope composition of the metasomatized mantle will thus reflect a simple binary mixing between the mantle and the metasomatizing agent.

The $\mathrm{Cl}$ concentration of the mantle is low with estimates ranging from 0.4 to $10 \mathrm{ppm}$ (e.g. Lassiter et al., 2002; Saal et al., 2002; Salters and Stracke, 2004; Workman and Hart, 2005). To estimate the $\mathrm{Cl} / \mathrm{K}_{2} \mathrm{O}$ of the mantle source we used the MORB data from Michael and Cornell (1998), who suggest a $\mathrm{Cl} / \mathrm{K}_{2} \mathrm{O}$ around 0.02 . MORB has been proposed to have $\delta^{37} \mathrm{Cl}$ values varying from -1.03 to $0.37 \%$ (Sharp et al., 2013).

Chlorine present in subduction zones fluids can originate from 3 different sources: sediments and their associated marine pore fluids, serpentinites, and altered oceanic 
crust (AOC). Figure 6 represents a simple model of the contribution of aqueous dehydration fluids for each of the subduction end-members. Aqueous fluids were chosen in this model as $\mathrm{Cl}$ has a stronger affinity for aqueous fluids rather than for supercritical fluids or melt (Van den Bleeken and Koga, 2015), implying that aqueous fluids represent a larger $\mathrm{Cl}$ reservoir.

Sediments have a $\delta^{37} \mathrm{Cl}$ varying from $\sim+2$ to $-3 \%$, with most non-evaporite marine samples having negative $\delta^{37} \mathrm{Cl}$ values (Arcuri and Brimhall, 2003; Barnes et al., 2008, 2009b; John et al., 2010; Selverstone and Sharp, 2015). As no data exists for $\mathrm{Cl} / \mathrm{K}_{2} \mathrm{O}$ ratio of fluids issued from sediment dehydration we used the values from marine pore water. These fluids have $\sim 0.07 \mathrm{wt} \% \mathrm{~K}_{2} \mathrm{O}$ (Godon et al., 2004a) and 1-2 wt\% $\mathrm{Cl}$ (Ransom et al., 1995; Spivack et al., 2002; Godon et al., 2004a; Bonifacie et al., 2007b), and we consequently used an average $\mathrm{Cl} / \mathrm{K}_{2} \mathrm{O}$ ratio of 21 for fluids deriving from sediments dehydration.

For the second end-member, three types of serpentinites can be distinguished: seafloor serpentinites, subducted serpentinites and mantle wedge serpentinites (see Deschamps et al., 2013 for a review). Most seafloor serpentinites have slightly positive $\delta^{37} \mathrm{Cl}$ values $(\sim 0.0$ to $+0.5 \%)$ due to interaction with seawater. However, some seafloor serpentinites are negative (down to $-1.6 \% 0$ ) due to interaction with sediments and/or sedimentary pore water (Barnes and Sharp, 2006; Barnes et al., 2008, 2009b; Bonifacie et al., 2008a). Serpentinized mantle wedge and subducted serpentinites will inherit the $\delta^{37} \mathrm{Cl}$ signature of the more variable fluids responsible for the serpentinization in this regime. Indeed, a range of $\delta^{37} \mathrm{Cl}$ from -1.5 to $+2.4 \%$ o has been reported for the latter (e.g. Bonifacie et al., 2008a; John et al., 2011; Barnes et al., 2013, 2014). The three types of serpentinites have $\mathrm{Cl}$ contents ranging from 200 to $4000 \mathrm{ppm}$, with a mean values of $1105 \pm 596$ ppm (Barnes and Sharp, 2006; Bonifacie et al., 2008a; John et al., 2011; Kodolànyi and Pettke, 2011; Kendrick et al., 2013). It has been proposed that fluids originating from serpentinite dehydration are enriched in Cl. Scambelluri et al. (2004) calculated that fluids from serpentinite dehydration at antigorite breakdown might reach $0.2-0.4$ wt $\% \mathrm{NaCl}_{\text {eq }}$ based on fluid inclusions. As serpentinites have typically very low $\mathrm{K}$ concentrations, we assumed here that little or no $\mathrm{K}$ escapes in the dehydration fluids. We arbitrarily used $0.01 \mathrm{wt} \%$ for $\mathrm{K}_{2} \mathrm{O}$ in these fluids, which corresponds to the detection limit for $\mathrm{K}_{2} \mathrm{O}$ measurement by EMPA, leading to fluids resulting from serpentinite dehydration with $\mathrm{Cl} / \mathrm{K}_{2} \mathrm{O}$ of 30 . As we used a single $\mathrm{Cl} / \mathrm{K}_{2} \mathrm{O}$ ratios and the 
whole range of $\delta^{37} \mathrm{Cl}$ published for all serpentinites, no distinction can be made between lithospheric serpentinite or serpentinized mantle wedge in this model.

The third end-member, $\mathrm{AOC}$ is characterized by a $\delta^{37} \mathrm{Cl}$ ranging from -1.4 to $+1.8 \%$ and contains 100-900 ppm Cl (Barnes and Cisneros, 2012). As fluids generated by dehydration of K-bearing subducted lithologies tend to be rather enriched in $\mathrm{K}_{2} \mathrm{O}$ (e.g. Stalder et al., 2002; Luginbühl, 2015), we roughly estimated a $\mathrm{Cl} / \mathrm{K}_{2} \mathrm{O}$ ratio of 1 for fluids deriving from AOC.

In the following, we compare $\delta^{37} \mathrm{Cl}$ of melt inclusions with $\mathrm{Cl}$ originating from different end-members. The melt inclusions from basaltic rocks from St-Vincent and Aoba cover a similar range in $\delta^{37} \mathrm{Cl}\left(-1.9\right.$ to $+0.6 \%$ and -1.7 to $+0.4 \%$ respectively) and $\mathrm{Cl} / \mathrm{K}_{2} \mathrm{O}$ ratios (0.22-0.35 and 0.15-0.32 respectively), whereas the Aeolian Island melt inclusions have different $\delta^{37} \mathrm{Cl}$ values (i.e., from -3.4 to $-1.4 \% 0$ ). It is evident from Figure 6 that, based solely on $\delta^{37} \mathrm{Cl}$ values, the respective contributions from serpentinite or $\mathrm{AOC}$ dehydration could not easily be distinguished for St-Vincent and Aoba. Simple mixing calculation using the whole range of $\delta^{37} \mathrm{Cl}$ and average $\mathrm{Cl} / \mathrm{K}_{2} \mathrm{O}$ ratios indicates that only a minor proportion $(<2 \%)$ of fluids derived from serpentinites are required to explain the $\mathrm{Cl}$ and $\delta^{37} \mathrm{Cl}$ composition of melt inclusions from St-Vincent or Vanuatu, whereas up to $35 \%$ would be required for a contribution from AOC. We thus suggest that $\delta^{37} \mathrm{Cl}$ signature of those melt inclusions is mainly controlled by the $\mathrm{Cl}$ originating from serpentinites. Such proportions of serpentinite fluids are consistent with the data from Métrich and Deloule (2014), who suggested that up to $0.7 \%$ of fluids derived from the ultramafic part of the slab and serpentinites, based on $\delta^{11} \mathrm{~B}$ in melt inclusions, could explain the Aoba melt inclusions composition. Serpentinite influence was also suggested for St-Vincent melt inclusions, together with AOC and sediment fluids (Bouvier et al., 2008, 2010). The sediment input beneath St-Vincent was suggested to be significant (up to $25 \%$ ), slightly higher than suggestions based on bulk rocks data (15\%; Turner et al., 1996; Van Soest et al., 2002) whereas it is not reflected in the present model. This could be explained by 1 - the fact that sediments subducted beneath St. Vincent do not have a strongly negative chlorine isotopic signature, making it hard to decipher from serpentinite and $\mathrm{AOC}$, using only $\mathrm{Cl}$ and $\delta^{37} \mathrm{Cl}$, or 2- the influence of a serpentinized mantle wedge created by early dehydration of sediments. In contrast, the distinct $\delta^{37} \mathrm{Cl}$ of Aeolian melt inclusions cannot exclusively be explained by $\mathrm{Cl}$ coming from fluids from AOC or serpentinites, but rather by the addition of a fluid derived from sediments. 
The different $\delta^{37} \mathrm{Cl}$ observed for the Aeolian melt inclusions could thus be due to different subducted sediments and/or different depth/temperature of the slab, which can lead, for example, to the dehydration of different parts of the subducted lithosphere. For St-Vincent and Aoba, although the range of $\delta^{37} \mathrm{Cl}$ values of melt inclusions is similar, the subducted sediments are of different nature (mostly terrigenous for St-Vincent (e.g. Carpentier et al., 2008) and volcanoclastic for Aoba (e.g. Peate et al., 1997). Moreover, as in St-Vincent, sediments subducted beneath the Aeolian Island are mostly terrigenous (Klaver et al., 2015), suggesting that the difference in $\delta^{37} \mathrm{Cl}$ for the Aeolian melt inclusions cannot be explained solely by the nature of the subducted sediments. Interestingly, dip angles of the slabs beneath St. Vincent and Aoba is $\sim 40-50^{\circ}$ (e.g. Wadge and Shepherd, 1984; Baillard et al., 2015) whereas it is steeper beneath the Aeolian island $\left(\sim 70^{\circ}\right.$; Calò et al., 2012) which impacts on the temperature structure of the slab. A hotter P-T path has been suggested by Syracuse et al. (2010) for St. Vincent and Aoba (thermal parameter/100 (km) value of 10.4 and 19.4, respectively) than for the Aeolian Island (thermal parameter $100(\mathrm{~km})$ of 58.3 for Calabria). A cooler P-T path will, for example, allow a longer survival time of the sediments. Similarly, many of the back-arc Lau basin melt inclusions (19 of 24) have $\delta^{37} \mathrm{Cl}$ and $\mathrm{Cl} / \mathrm{K}_{2} \mathrm{O}$ comparable to StVincent and Aoba melt inclusions and is also associated with a subduction zone with a comparable slab dip angle ( $45^{\circ}$; e.g. Harmon and Blackman, 2010). The significant difference of $\delta^{37} \mathrm{Cl}$ in melt inclusions of Aeolian islands compare to St-Vincent and Aoba could thus reflect difference in the subduction zone geometry, as already suggested by Barnes et al. (2009).

The current results suggest that $\delta^{37} \mathrm{Cl}$ values of melt inclusions can provide valuable information about the behavior of $\mathrm{Cl}$ and its isotopes in subduction zones, even if additional measurements are necessary to understand the rather large variation within a single sample and to quantify the respective contributions of the different $\mathrm{Cl}$ sources in the mantle and subducted oceanic lithosphere.

\section{Conclusion}

Dual-FC SIMS allows for fast high-precision, in-situ measurement of $\mathrm{Cl}$ isotope compositions in glasses with $\mathrm{Cl}$ concentration higher than $900 \mathrm{ppm}$. Precision approaches that for Pyro-IRMS analysis for non-soluble, solid samples and is appropriate to trace different chlorine isotope signatures of melt inclusions from 
volcanic arc settings. Melt inclusions and glasses of various compositions can be analysed with the set of standards we developed.

First in situ $\delta^{37} \mathrm{Cl}$ measurements of melt inclusions from subduction zones reveal large $\delta^{37} \mathrm{Cl}$ variations within a single sample and within an arc without any correlation with the $\mathrm{Cl}$ content of the melt inclusions. For St Vincent and Aoba melt inclusions, the current dataset suggest that the source of $\mathrm{Cl}$ addition under both islands is provided by fluids most realistically originating from serpentinite. Melt inclusions from Aeolian Islands have distinct $\delta^{37} \mathrm{Cl}$ values compared to St-Vincent and Aoba, suggesting the influence of a fluid deriving from sediments. The difference in chlorine isotopes between the different arc settings might reflect the different slab geometry, and hence thermal structure. However, further work is required to better understand this difference, as well as the large variation within an individual sample. However, this preliminary study also suggests that $\delta^{37} \mathrm{Cl}$ in melt inclusions is a valuable tool to better constrain the origin of the $\mathrm{Cl}$ added to the mantle wedge, providing new constraints to refine the current models of $\mathrm{Cl}$ redistribution into the crust-mantle system related to subduction zone processes.

\section{Acknowledgments}

EFR-K thanks Federica Schiavi for her assistance with the Raman spectroscopy. We thank Z. Sharp for Pyro-IRMS analyses of glasses. We thanks Dr. A. Gurenko and an anonymous reviewer for their useful suggestions. The editorial handling of Dr. C. Chauvel was greatly appreciated. We acknowledge funding by the Center for Advanced Surface Analysis (funded by the Swiss University Conference and Ecole Polytechnique Fédérale de Lausanne). 


\section{References}

Arcuri, T., Brimhall, G., 2003. The chloride source for atacamite mineralization at the Radomiro Tomic porphyry copper deposit, northern Chile. Econ. Geol. 98, 16671681. doi:10.2113/gsecongeo.98.8.1667

Baillard, C., Crawford, C.W., Ballu, V., Régnier, M., Pelletier, B., Garaebiti, E., 2015. Journal of Geophysical Research?: Solid Earth. J. Geophys. Res. Solid Earth 5606-5623. doi:10.1002/2012JB010016.1.

Barnes, J.D., Beltrando, M., Lee, C.T.A., Cisneros, M., Loewy, S., Chin, E., 2014. Geochemistry of Alpine serpentinites from rifting to subduction: A view across paleogeographic domains and metamorphic grade. Chem. Geol. 389, 29-47. doi:10.1016/j.chemgeo.2014.09.012

Barnes, J.D., Cisneros, M., 2012. Mineralogical control on the chlorine isotope composition of altered oceanic crust. Chem. Geol. 326, 51-60. doi:10.1016/j.chemgeo.2012.07.022

Barnes, J.D., Eldam, R., Lee, C.T.A., Errico, J.C., Loewy, S., Cisneros, M., 2013. Petrogenesis of serpentinites from the franciscan complex, western california, USA. Lithos 178, 143-157. doi:10.1016/j.lithos.2012.12.018

Barnes, J.D., Paulick, H., Sharp, Z.D., Bach, W., Beaudoin, G., 2009a. Stable isotope $\delta 180$, $\delta \mathrm{D}, \delta 37 \mathrm{Cl}$ evidence for multiple fluid histories in mid-Atlantic abyssal peridotites (ODP Leg 209). Lithos 110, 83-94. doi:10.1016/j.lithos.2008.12.004

Barnes, J.D., Selverstone, J., Sharp, Z.D., 2006. Chlorine isotope chemistry of serpentinites from Elba, Italy, as an indicator of fluid source and subsequent tectonic history. Geochemistry, Geophys. Geosystems 7. doi:10.1029/2006GC001296

Barnes, J.D., Sharp, Z.D., 2006. A chlorine isotope study of DSDP/ODP serpentinized ultramafic rocks: Insights into the serpentinization process. Chem. Geol. 228, 246265. doi:10.1016/j.chemgeo.2005.10.011

Barnes, J.D., Sharp, Z.D., Fischer, T.P., 2008. Chlorine isotope variations across the IzuBonin-Mariana arc. Geology 36, 883-886. doi:10.1130/G25182A.1

Barnes, J.D., Sharp, Z.D., Fischer, T.P., Hilton, D.R., Carr, M.J., 2009b. Chlorine isotope variations along the Central American volcanic front and back arc. Geochemistry, Geophys. Geosystems 10. doi:10.1029/2009GC002587

Barnes, J.D., Straub, S.M., 2010. Chorine stable isotope variations in Izu Bonin tephra: Implications for serpentinite subduction. Chem. Geol. 272, 62-74. doi:10.1016/j.chemgeo.2010.02.005

Bevington, P.R., Robinson, K.D., 2002. Data reduction and error analysis for the physical sciences, 3rd ed. McGraw-Hill Education.

Bonifacie, M., Busigny, V., Mével, C., Philippot, P., Agrinier, P., Jendrzejewski, N., Scambelluri, M., Javoy, M., 2008a. Chlorine isotopic composition in seafloor serpentinites and high-pressure metaperidotites. Insights into oceanic serpentinization and subduction processes. Geochim. Cosmochim. Acta 72, 126139. doi:10.1016/j.gca.2007.10.010

Bonifacie, M., Jen, Agrinier, P., Coleman, M., Pineau, F., Javoy, M., 2007a. PyrohydrolysisIRMS determination of silicate chlorine stable isotope compositions. Application to oceanic crust and meteorite samples. Chem. Geol. 242, 187-201. doi:10.1016/j.chemgeo.2007.03.012

Bonifacie, M., Jendrzejewski, N., Agrinier, P., Humler, E., Coleman, M., Javoy, M., 2008b. The Chlorine Isotope Composition of Earth's Mantle. Science (80-. ). 319, 15181520. doi:10.1126/science.1150988 
Bonifacie, M., Monnin, C., Jendrzejewski, N., Agrinier, P., Javoy, M., 2007b. Chlorine stable isotopic composition of basement fluids of the eastern flank of the Juan de Fuca Ridge (ODP Leg 168). Earth Planet. Sci. Lett. 260, 10-22. doi:10.1016/j.epsl.2007.05.011

Bouvier, A.-S., Deloule, E., Métrich, N., 2010. Fluid Inputs to Magma Sources of St. Vincent and Grenada (Lesser Antilles): New Insights from Trace Elements in Olivine-hosted Melt Inclusions. J. Petrol. 51, 1597-1615. doi:10.1093/petrology/egq031

Bouvier, A.-S., Deloule, E., Métrich, N., 2008. Slab-Derived Fluids in the Magma Sources of St . Vincent ( Lesser Antilles Arc ): Volatile and Light Element Imprints. J. Petrol. 49, 1427-1448. doi:10.1093/petrology/egn031

Calò, M., Dorbath, C., Luzio, D., Rotolo, S.G., D’Anna, G., 2012. Seismic velocity structures of southern Italy from tomographic imaging of the Ionian slab and petrological inferences. Geophys. J. Int. 191, 751-764. doi:10.1111/j.1365-246X.2012.05647.x

Carpentier, M., Chauvel, C., Mattielli, N., 2008. Pb-Nd isotopic constraints on sedimentary input into the Lesser Antilles arc system. Earth Planet. Sci. Lett. 272, 199-211. doi:10.1016/j.epsl.2008.04.036

Chiaradia, M., Barnes, J.D., Cadet-Voisin, S., 2014. Chlorine stable isotope variations across the Quaternary volcanic arc of Ecuador. Earth Planet. Sci. Lett. 396, 22-33. doi:10.1016/j.epsl.2014.03.062

Danyushevsky, L. V., Plechov, P., 2011. Petrolog3: Integrated software for modeling crystallization processes. Geochemistry, Geophys. Geosystems 12. doi:10.1029/2011GC003516

Danyushevsky, L. V, Della, F.N., Sokolov, S., 2000. Re-equilibration of melt inclusions trapped by magnesian olivine phenocrysts from subduction-related magmas?: petrological implications. Contrib. to Mineral. Petrol. 138, 68-83.

Danyushevsky, L. V, Sokolov, S., Falloon, T.J., 2002. Melt Inclusions in Olivine Phenocrysts?: Using Diffusive Re-equilibration to Determine the Cooling History of a Crystal , with Implications for the Origin of Olivine-phyric Volcanic Rocks. J. Petrol. 43, 1651-1671. doi:10.1093/petrology/43.9.1651

Davidson, J., 1985. Mechanisms of contamination in Lesser Antilles island arc magmas from radiogenic and oxygen isotope relationships. Earth Planet. Sci. Lett. 72, 163174. doi:10.1016/0012-821X(85)90003-2

Deschamps, F., Godard, M., Guillot, S., Hattori, K., 2013. Geochemistry of subduction zone serpentinites: A review. Lithos 178, 96-127. doi:10.1016/j.lithos.2013.05.019

Duffy, J.A., 1993. A review of optical basicity and its applications to oxidic systems. Geochim. Cosmochim. Acta 57, 3961-3970. doi:10.1016/0016-7037(93)90346-X

Eggenkamp, H.G.M., 1994. The geochemistry of chlorine isotopes. PhD Thesis, Univ. Utr.

Eggins, S.M., 1993. Origin and differentiation of picritic arc magmas, Ambae (Aoba), Vanuatu. Contrib. to Mineral. Petrol. 114, 79-100. doi:10.1007/BF00307867

Eiler, J.M., Graham, C., Valley, J.W., 1997. SIMS analysis of oxygen isotopes: matrix effects in complex minerals and glasses. Chem. Geol. 138, 221-244. doi:PII S0009-2541_ 97. 00015-6

Giunta, T., Ader, M., Bonifacie, M., Agrinier, P., Coleman, M., 2015. Pre-concentration of chloride in dilute water-samples for precise $\delta 37 \mathrm{Cl}$ determination using a strong ion-exchange resin: Application to rainwaters. Chem. Geol. 413, 86-93. doi:10.1016/j.chemgeo.2015.08.019

Godon, A., Jendrzejewski, N., Castrec-Rouelle, M., Dia, A., Pineau, F., Boulégue, J., Javoy, M., 2004a. Origin and evolution of fluids from mud volcanoes in the Barbados accretionary complex. Geochim. Cosmochim. Acta 68, 2153-2165. 
doi:10.1016/j.gca.2003.08.021

Godon, A., Jendrzejewski, N., Eggenkamp, H.G.M., Banks, D.A., Ader, M., Coleman, M.L., $2004 \mathrm{~b}$. A cross-calibration of chlorine isotopic measurements and suitability of seawater as the international reference material. chemical 207, 1-12. doi:10.1016/j.chemgeo.2003.11.019

Godon, A., Webster, J.D., Layne, G.D., Pineau, F., 2004c. Secondary ion mass spectrometry for the determination of $\delta 37 \mathrm{Cl}$ Part II. Intercalibration of SIMS and IRMS for aluminosilicate glasses. Chem. Geol. 207, 291-303. doi:10.1016/j.chemgeo.2004.04.003

Halldórsson, S.A., Barnes, J.D., Stefánsson, A., Hilton, D.R., Hauri, E.H., Marshall, E.W., 2016. Subducted lithosphere controls halogen enrichments in the Iceland mantle plume source. Geology 44, 679-682. doi:10.1130/G37924.1

Harmon, N., Blackman, D.K., 2010. Effects of plate boundary geometry and kinematics on mantle melting beneath the back-arc spreading centers along the Lau Basin. Earth Planet. Sci. Lett. 298, 334-346. doi:10.1016/j.epsl.2010.08.004

Heath, E., Turner, S.P., Macdonald, R., Hawkesworth, C.J., van Calsteren, P., 1998. Long magma residence times at an island arc volcano (Soufriere, St. Vincent) in the Lesser Antilles: evidence from 238U-230Th isochron dating. Earth Planet. Sci. Lett. 160, 49-63. doi:10.1016/S0012-821X(98)00084-3

Hernlund, J., Leinenweber, K., Locke, D., Tyburczy, J.A., 2006. A numerical model for steady-state temperature distributions in solid-medium high-pressure cell assemblies. Am. Mineral. 91, 295-305. doi:10.2138/am.2006.1938

Ito, E., Harris, D.M., Anderson, A.T., 1983. Alteration of oceanic crust and geologic cycling of chlorine and water. Geochim. Cosmochim. Acta 47, 1613-1624. doi:10.1016/0016-7037(83)90188-6

Jochum, K.P., Stoll, B., Herwig, K., Willbold, M., Hofmiann, A.W., Amini, M., Aarburg, S., Abouchami, W., Hellebrand, E., Mocek, B., Raczek, I., Stracke, A., Alard, O., Bouman, C., Becker, S., Dücking, M., Brätz, H., Klemd, R., De Bruin, D., Canil, D., Cornell, D., De Hoog, C.J., Dalpé, C., Danyushevshy, L., Eisenhauer, A., Gao, Y., Snow, J.E., Groschopf, N., Günther, D., Latkoczy, C., Guillong, M., Hauri, E.H., Höfer, H.E., Lahaye, Y., Horz, K., Jacob, D.E., Kasemann, S.A., Kent, A.J.R., Ludwig, T., Zack, T., Mason, P.R.D., Meixner, A., Rosner, M., Misawa, K., Nash, B.P., Pfänder, J., Premo, W.R., Sun, W.D., Tiepolo, M., Vannucci, R., Vennemann, T., Wayne, D., Woodhead, J.D., 2006. MPI-DING reference glasses for in situ microanalysis: New reference values for element concentrations and isotope ratios. Geochemistry, Geophys. Geosystems 7, 1-44. doi:10.1029/2005GC001060

John, T., Layne, G.D., Haase, K.M., Barnes, J.D., 2010. Chlorine isotope evidence for crustal recycling into the Earth's mantle. Earth Planet. Sci. Lett. 298, 175-182. doi:10.1016/j.epsl.2010.07.039

John, T., Scambelluri, M., Frische, M., Barnes, J.D., Bach, W., 2011. Dehydration of subducting serpentinite: Implications for halogen mobility in subduction zones and the deep halogen cycle. Earth Planet. Sci. Lett. 308, 65-76. doi:10.1016/j.epsl.2011.05.038

Kaufmann, R., Long, A., Bentley, H., Davis, S., 1984. Natural chlorine isotope variations. Nature 309, 338-340. doi:10.1038/309338a0

Kendrick, M.A., Honda, M., Pettke, T., Scambelluri, M., Phillips, D., Giuliani, A., 2013. Subduction zone fluxes of halogens and noble gases in seafloor and forearc serpentinites. Earth Planet. Sci. Lett. 365, 86-96. doi:10.1016/j.epsl.2013.01.006

Kent, A.J.R., 2008. Melt Inclusions in Basaltic and Related Volcanic Rocks. Rev. Mineral. 
Geochemistry 69, 273-331. doi:10.2138/rmg.2008.69.8

Kent, A.J.R., Peate, D.W., Newman, S., Stolper, E.M., Pearce, J.A., 2002. Chlorine in submarine glasses from the Lau Basin: Seawater contamination and constraints on the composition of slab-derived fluids. Earth Planet. Sci. Lett. 202, 361-377. doi:10.1016/S0012-821X(02)00786-0

Klaver, M., Djuly, T., de Graaf, S., Sakes, A., Wijbrans, J., Davies, G., Vroon, P., 2015. Temporal and spatial variations in provenance of Eastern Mediterranean Sea sediments: Implications for Aegean and Aeolian arc volcanism. Geochim. Cosmochim. Acta 153, 149-168. doi:10.1016/j.gca.2015.01.007

Kodolànyi, J., Pettke, T., 2011. Loss of trace elements from serpentinites during fluidassisted transformation of chrysotile to antigorite - An example from Guatemala. Chem. Geol. 284, 351-362. doi:10.1016/j.chemgeo.2011.03.016

Lassiter, J.C., Hauri, E.H., Nikogosian, I.K., Barsczus, H.G., 2002. Chlorine-potassium variations in melt inclusions from Raivavae and Rapa, Austral Islands?: constraints on chlorine recycling in the mantle and evidence for brine-induced melting of oceanic crust. Earth Planet. Sci. Lett. 202, 525-540.

Layne, G., Godon, A., Webster, J., Bach, W., 2004. Secondary ion mass spectrometry for the determination of $\delta 37 \mathrm{Cl}$ Part I. Ion microprobe analysis of glasses and fluids. Chem. Geol. 207, 277-289. doi:10.1016/j.chemgeo.2004.04.002

Layne, G.D., Kent, A.J.R., Bach, W., Layne, G.D., Kent, A.J.R., Bach, W., 2009. $\delta 37 \mathrm{Cl}$ systematics of a backarc spreading system?: The Lau Basin. Geology 37, 427-430. doi:10.1130/G25520A.1

Le Voyer, M., Asimow, P.D., Mosenfelder, J.L., Guan, Y., Wallace, P.J., Schiano, P., Stolper, E.M., Eiler, J.M., 2014. Zonation of H2O and F Concentrations around Melt Inclusions in Olivines. J. Petrol. 55,1-23. doi:10.1093/petrology/egu003

Li, L., Bonifacie, M., Aubaud, C., Crispi, O., Dessert, C., Agrinier, P., 2015. Chlorine isotopes of thermal springs in arc volcanoes for tracing shallow magmatic activity. Earth Planet. Sci. Lett. 413, 101-110. doi:10.1016/j.epsl.2014.12.044

Liebscher, A., Barnes, J., Sharp, Z., 2006. Chlorine isotope vapor liquid fractionation during experimental fluid-phase separation at $400^{\circ} \mathrm{C} / 23 \mathrm{MPa}$ to $450{ }^{\circ} \mathrm{C} / 42 \mathrm{MPa}$. Chem. Geol. 234, 340-345. doi:10.1016/j.chemgeo.2006.04.009

Luginbühl, S., 2015. Phase relations, composition and trace element partitioning of solid and mobile phases in the hydrous MORB system at 2-3 GPa. PhD Thesis, ETHZ.

Lyon, I.C., Saxton, J.M., Turner, G.F., Hinton, R.W., 1994. Isotopic fractionation in secondary ionization mass spectrometry. Rapid Commun. Mass Spectrom. 8, 837843. doi:10.1016/S0168-1176(97)00143-2

Macdonald, R., Hawkesworth, C.J., Heath, E., 2000. The Lesser Antilles volcanic chain: a study in arc magmatism. Earth Sci. Rev. 49, 1-76. doi:10.1016/S00128252(99)00069-0

Manning, C.E., 2004. The chemistry of subduction-zone fluids. Earth Planet. Sci. Lett. 223, 1-16. doi:10.1016/j.epsl.2004.04.030

Métrich, N., Deloule, E., 2014. Water content, $\delta \mathrm{D}$ and $\delta 11 \mathrm{~B}$ tracking in the Vanuatu arc magmas (Aoba Island): Insights from olivine-hosted melt inclusions. Lithos 206207, 400-408. doi:10.1016/j.lithos.2014.08.011

Métrich, N., Wallace, P.J., 2008. Volatile Abundances in Basaltic Magmas and Their Degassing Paths Tracked by Melt Inclusions. Rev. Mineral. Geochemistry 69, 363402. doi:10.2138/rmg.2008.69.10

Michael, P.J., Cornell, W.C., 1998. Influence of spreading rate and magma supply on crystallization and assimilation beneath mid-ocean ridges: Evidence from chlorine 
and major element chemistry of mid-ocean ridge basalts. J. Geophys. Res. 103, 18325-18356. doi:10.1029/98JB00791

Mysen, B.O., 1990. Relationships between silicate melt structure and petrologic processes. Earth Sci. Rev. 27, 281-365. doi:10.1016/0012-8252(90)90055-Z

Mysen, B.O., Virgo, D., Seifert, F.A., 1985. Relationships between properties and structure of aluminosilicate melts. Am. Mineral. 70, 88-105.

Peate, D.W., Pearce, J. a., Hawkesworth, C.J., Colley, H., Edwards, C.M.H., Hirose, K., 1997. Geochemical Variations in Vanuatu Arc Lavas: the Role of Subducted Material and a Variable Mantle Wedge Composition. J. Petrol. 38, 1331-1358. doi:10.1093/petroj/38.10.1331

Peccerillo, A., De Astis, G., Faraone, D., Forni, F., Frezzotti, M.L., 2013. Chapter 15 Compositional variations of magmas in the Aeolian arc: implications for petrogenesis and geodynamics. Geol. Soc. London, Mem. 37, 491-510. doi:10.1144/M37.15

Ransom, B., Spivack, A.J., Kastner, M., 1995. Stable Cl isotopes in subduction-zone pore waters?: Implications for fluid-rock reactions and the cycling of chlorine. Geology 23, 715-718. doi:10.1130/0091-7613(1995)023<0715:SCIISZ>2.3.CO;2

Raos, A.M., Crawford, A.J., 2004. Basalts from the Efate Island Group, central section of the Vanuatu arc, SW Pacific: geochemistry and petrogenesis. J. Volcanol. Geotherm. Res. 134, 35-56. doi:10.1016/j.jvolgeores.2004.12.004

Rizzo, A.L., Caracausi, A., Liotta, M., Paonita, A., Barnes, J.D., Corsaro, R.A., Martelli, M., 2013. Chlorine isotope composition of volcanic gases and rocks at Mount Etna (Italy) and inferences on the local mantle source. Earth Planet. Sci. Lett. 371, 134142. doi:10.1016/j.epsl.2013.04.004

Rose-Koga, E.F., Koga, K.T., Schiano, P., Voyer, L.M., 2012. Mantle source heterogeneity for South Tyrrhenian magmas revealed by $\mathrm{Pb}$ isotopes and halogen contents of olivine-hosted melt inclusions. Chem. Geol. 334, 266-279. doi:10.1016/j.chemgeo.2012.10.033

Saal, A.E., Hauri, E.H., Langmuir, C.H., Perfit, M.R., 2002. Vapour undersaturation in primitive mid-ocean-ridge basalt and the volatile content of Earth's upper mantle. Nature 419, 451-455.

Salters, V.J.M., Stracke, A., 2004. Composition of the depleted mantle. Geochemistry, Geophys. Geosystems 5. doi:10.1029/2003GC000597

Scambelluri, M., Müntener, O., Ottolini, L., Pettke, T.T., Vannucci, R., 2004. The fate of B , $\mathrm{Cl}$ and $\mathrm{Li}$ in the subducted oceanic mantle and in the antigorite breakdown fluids.

Earth Planet. Sci. Lett. 222, 217-234. doi:10.1016/j.epsl.2004.02.012

Scambelluri, M., Philippot, P., 2001. Deep fluids in subduction zones. Lithos 55, 213-227. doi:10.1016/S0024-4937(00)00046-3

Schauble, E. a, Rossman, G.R., Taylor, H.P.J., 2003. Theoretical estimates of equilibrium chlorine-isotope fractionations, Geochimica et Cosmochimica Acta. Geochim Cosmochim Acta 67, 3267-3281. doi:10.1016/S0016-7037(00)01375-3

Schiano, P., 2003. Primitive mantle magmas recorded as silicate melt inclusions in igneous minerals. Earth Sci. Rev. 63, 121-144. doi:10.1016/S0012-8252(03)000345

Schroeer, J.M., Rhodin, T.N., Bradley, R.C., 1973. A quantum-mechanical model for the ionization and excitation of atoms during sputtering. Surf. Sci. 34, 571-580. doi:10.1016/0039-6028(73)90026-5

Selverstone, J., Sharp, Z.D., 2015. Chlorine isotope behavior during prograde metamorphism of sedimentary rocks. Earth Planet. Sci. Lett. 417, 120-131. 
doi:10.1016/j.epsl.2015.02.030

Selverstone, J., Sharp, Z.D., 2013. Chlorine isotope constraints on fluid-rock interactions during subduction and exhumation of the Zermatt-Saas ophiolite. Geochemistry, Geophys. Geosystems 14, 4370-4391. doi:10.1002/ggge.20269

Sharp, Z.D., Barnes, J.D., Brearley, A.J., Chaussidon, M., Fischer, T.P., Kamenetsky, V.S., 2007. Chlorine isotope homogeneity of the mantle, crust and carbonaceous chondrites. Nature 446, 1062-1065. doi:10.1038/nature05748

Sharp, Z.D., Barnes, J.D., Fischer, T.P., Halick, M., 2010. An experimental determination of chlorine isotope fractionation in acid systems and applications to volcanic fumaroles. Geochim. Cosmochim. Acta 74, 264-273. doi:10.1016/j.gca.2009.09.032

Sharp, Z.D., Mercer, J.A., Jones, R.H., Brearley, A.J., Selverstone, J., Bekker, A., Stachel, T., 2013. The chlorine isotope composition of chondrites and Earth. Geochim. Cosmochim. Acta 107, 189-204. doi:10.1016/j.gca.2013.01.003

Shimizu, N., Hart, S.R., 1982. Isotope fractionation in secondary ion mass spectrometry. J. Appl. Phys. 53, 1303-1311.

Sigmund, P., 1969. Theory of sputtering. I. Sputtering yield of amorphous and polycrystalline targets. Phys. Rev. 184, 383-416. doi:10.1103/PhysRev.184.383

Sorbadère, F., Schiano, P., Métrich, N., Garaebiti, E., 2011. Insights into the origin of primitive silica-undersaturated arc magmas of Aoba volcano (Vanuatu arc). Contrib. to Mineral. Petrol. 162, 995-1009. doi:10.1007/s00410-011-0636-1

Spilliaert, N., Métrich, N., Allard, P., 2006. S - Cl - F degassing pattern of water-rich alkali basalt?: Modelling and relationship with eruption styles on Mount Etna volcano. Earth Planet. Sci. Lett. 248, 772-786. doi:10.1016/j.epsl.2006.06.031

Spivack, A.J., Kastner, M., Ransom, B., 2002. Elemental and Isotopic Chloride Geochemistry and Fluid Flow in the Nankai Trough. Geophys. Res. Lett. 29, 4-7. doi:10.1029/2001GL014122

Stalder, R., Ulmer, P., Gunther, D., 2002. Fluids in the system forsterite-phlogopite-H2O at 60 kbar. Schweizerische Mineral. Und Petrogr. Mitteilungen 82, 15-24.

Stolper, E., Newman, S., 1994. The role of water in the petrogenesis of Mariana trough magmas. Earth Planet. Sci. Lett. 121, 293-325. doi:10.1016/0012-821X(94)90074-4

Syracuse, E.M., van Keken, P.E., Abers, G.A., Suetsugu, D., Bina, C., Inoue, T., Wiens, D., Jellinek, M., 2010. The global range of subduction zone thermal models. Phys. Earth Planet. Inter. 183, 73-90. doi:10.1016/j.pepi.2010.02.004

Turner, S., Hawkesworth, C., Van calsteren, P., Heath, E., Macdonald, R., Black, S., 1996. Useries isotopes and destructive plate margin magma genesis in the Lesser Antilles. Earth Planet. Sci. Lett. 142, 191-207. doi:10.1016/0012-821X(96)00078-7

Valley, J.W., Graham, C.M., 1991. Ion microprobe analysis of oxygen isotope ratios in granulite facies magnetites: diffusive exchange as a guide to cooling history. Contrib. to Mineral. Petrol. 109, 38-52. doi:10.1007/BF00687199

Van den Bleeken, G., Koga, K.T., 2015. Experimentally determined distribution of fluorine and chlorine upon hydrous slab melting, and implications for F-Cl cycling through subduction zones. Geochim. Cosmochim. Acta 171, 353-373. doi:10.1016/j.gca.2015.09.030

Van Soest, M.C., Hilton, D.R., Macpherson, C.G., Mattey, D.P., 2002. Resolving Sediment Subduction and Crustal Contamination in the Lesser Antilles Island Arc: a Combined He-O-Sr Isotope Approach. J. Petrol. 43, 143-170. doi:10.1093/petrology/43.1.143

Wadge, G., Shepherd, J.B., 1984. Segmentation of the Lesser Antilles subduction zone. Earth Planet. Sci. Lett. 71, 297-304. doi:10.1016/0012-821X(84)90094-3

Warden, A.J., 1970. Evolution of Aoba caldera volcano, New Hebrides. Bull. Volcanol. 34, 
107-140. doi:10.1007/BF02597781

Westbrook, G.K., 1975. The structure of the crust and upper mantle in the region of Barbados and the Lesser Antilles. J. R. Astron. Soc. 43, 201-237. doi:10.1111/j.1365-246X.1975.tb00632.x

White, W.M., Dupré, B., 1986. Sediment subduction and magma genesis in the Lesser Antilles: isotopic and trace element constraints. J. Geophys. Res. Solid Earth 91, 5927-5941. doi:10.1029/JB091iB06p05927

White, W.M., Patchett, P.J., 1984. Hf-Nd-Sr isotopes and incompatible element abundances in island arcs: implications for magma origins and crust-mantle evolution. Earth Planet. Sci. Lett. 67, 167-185. doi:10.1016/0012-821X(84)90112-2

Williams, P., 1979. The sputtering process and sputtered ion emission. Mater. Res. 90, 588-634. doi:10.1016/0039-6028(79)90363-7

Workman, R.K., Hart, S.R., 2005. Major and trace element composition of the depleted MORB mantle (DMM). Earth Planet. Sci. Lett. 231, 53-72. doi:10.1016/j.epsl.2004.12.005

Yardley, B.W.., 1997. The evolution of fluids through the metamorphic cycle. In: Jamtveit B., Yardley B.W.D (Eds.), Fluid flow and transport in rocks: mechanisms and effects. London Chapman Hall 99-121.

Yu, M.L., Lang, N.D., 1986. Section II . Atomic mechanisms ejection of atomic ion emissopm during sputtering. Nucl. Instruments Methods Phys. Res. Sect. B Beam Interact. with Mater. Atoms B14, 403-413. 


\section{Table 1}

Major elements composition and $\mathrm{Cl}$ concentration (wt\%) are measured by EMPA and $\delta^{37} \mathrm{Cl}(\% 0)$ measured in-situ by SIMS at Lausanne and by bulk analysis by Pyro-IRMS at both Institut de Physique du Globe de Paris, University of New Mexico and the University of Texas at Austin for the glasses used as standards in this study.

Reported uncertainty (2SD) represents the reproducibility of the measurements on the same glass. Note however that long-term external reproducibility on rock standards in respective laboratories are mostly larger (ie., $\pm 0.28 \%$ in IPGP, $\pm 0.80 \%$ in $\mathrm{UNM}$; Selverstone and Sharp (2013) and $\pm 0.40 \%$ at UT) than the uncertainties reported here for the replicate $\delta^{37} \mathrm{Cl}$ measurements of unknown glass samples. The IMF uncertainty takes into account the uncertainty of the measurement by SIMS and Pyro-IRMS. 


\begin{tabular}{|c|c|c|c|c|c|c|}
\hline sample & UNIL_GI-B4 & UNIL_GI-B6 & UNIL_GI-B7 & $\mathrm{RMR}^{*}$ & PR2* & IB94* \\
\hline $\mathrm{SiO}_{2}(w \mathrm{t} \%)$ & $56.85(0.54)$ & $43.41(0.89)$ & $50.71(0.29)$ & 76.39 & 74.16 & 51.89 \\
\hline$K_{2} O \quad(w t \%)$ & $4.34(0.08)$ & $0.33(0.02)$ & $0.18(0.03)$ & 4.42 & 4.39 & 0.46 \\
\hline $\mathrm{Na}_{2} \mathrm{O}(w t \%)$ & $2.91(0.13)$ & $3.23(0.13)$ & $2.66(0.16)$ & 4.36 & 5.52 & 2.42 \\
\hline $\mathrm{TiO}_{2}(w \mathrm{t} \%)$ & $1.32(0.05)$ & $1.17(0.05)$ & $0.58(0.05)$ & 0.1 & 0.24 & 1.08 \\
\hline FeO (wt\%) & - & - & - & 1.02 & 3.99 & 12.87 \\
\hline $\mathrm{Fe}_{2} \mathrm{O}_{3}(\mathrm{wt} \%)$ & $11.31(0.26)$ & $9.11(0.21)$ & $11.00(0.18)$ & - & & - \\
\hline $\mathrm{Al}_{2} \mathrm{O}_{3}(\mathrm{wt} \%)$ & $14.25(0.18)$ & $18.09(0.23)$ & $13.81(0.14)$ & 1215 & 10.44 & 15.28 \\
\hline Mg0 (wt\%) & $4.90(0.12)$ & $16.86(0.25)$ & $10.69(0.18)$ & 0.02 & 0.05 & 4.42 \\
\hline $\mathrm{CaO}$ (wt\%) & $2.49(0.06)$ & $6.19(0.14)$ & $7.04(0.17)$ & 0.28 & 0.18 & 9.36 \\
\hline MnO (wt\%) & $0.04(0.03)$ & $0.05(0.02)$ & $0.06(0.03)$ & 03 & 0.09 & 0.22 \\
\hline $\mathrm{H}_{2} \mathrm{O}(\mathrm{wt} \%)$ & n.d. & 0.5 & 1.3 & 0.3 & 0.32 & 1.9 \\
\hline Cl (wt\%) & $0.30(0.02)$ & $0.31(0.02)$ & $3.26(0.08)$ & 0.17 & 0.21 & 0.15 \\
\hline$\delta^{37} \mathrm{Cl}$ SIMS (\%o) & $9.05(0.17)$ & $6.30(0.19)$ & $5.61(0.05)$ & $8.62(0.73)$ & $8.45(0.22)$ & $6.62(0.52)$ \\
\hline n SIMS & 6 & 6 & 10 & 6 & 6 & 6 \\
\hline $\begin{array}{c}\delta^{37} \mathrm{Cl} \text { Pyro-IRMS } \\
\text { (Paris) (\%o vs } \\
\text { SMOC) }\end{array}$ & n.d. & $\begin{array}{c}1.84(0.08, \\
n=1)\end{array}$ & $\begin{array}{c}-0.11(0.62 \\
n=3)\end{array}$ & $0.29(0.06) \#$ & n.d. & n.d. \\
\hline $\begin{array}{c}\delta^{37} \mathrm{Cl} \text { Pyro-IRMS } \\
\text { (New Mexico) } \\
\text { (\%o vs SMOC) }\end{array}$ & $0.03(n=1)$ & $\begin{array}{r}1.70(0 \\
n=2\end{array}$ & $\begin{array}{c}0.23(0.38 \\
n=3)\end{array}$ & $-1.1(n=1)$ & $-1.13(n=1)$ & $\begin{array}{c}1.52(0.42, \\
n=2)\end{array}$ \\
\hline $\begin{array}{c}\delta^{37} \mathrm{Cl} \text { Pyro-IRMS } \\
\text { (Austin) (\%o vs } \\
\text { SMOC) }\end{array}$ & n.d. & & n.d. & $\begin{array}{c}-0.78(0.62 \\
n=4)\end{array}$ & $\begin{array}{c}-0.72(0.54 \\
n=5)\end{array}$ & n.d. \\
\hline $\begin{array}{c}\delta^{37} \mathrm{Cl} \text { Pyro-IRMS } \\
\text { (accepted) (\%o } \\
\text { vs SMOC) }\end{array}$ & $0.03(0.40)$ & $1.77(0.20)$ & $0.21(0.31)$ & $\begin{array}{l}-0.84 \\
(0.60)\end{array}$ & $\begin{array}{l}-0.79 \\
(0.58)\end{array}$ & $1.52(0.42)$ \\
\hline IMF (\%o) & $9.02(0.40)$ & $4.53(0.28)$ & $5.40(0.69)$ & $9.46(0.94)$ & $9.24(0.62)$ & $5.10(0.67)$ \\
\hline
\end{tabular}


Table 2

Experimental conditions used to synthetize the 3 new glass standards.

\begin{tabular}{|c|c|c|c|c|c|}
\hline & $\mathrm{T}\left({ }^{\circ} \mathrm{C}\right)$ & $\mathrm{P}$ (kbar) & $\mathrm{t}(\min )$ & Assembly & TC/tubing \\
\hline UNIL_GL-B4 \#1 & 1400 & 7 & 120 & Tlc-Pxrex-MgO & $\mathrm{B} / \mathrm{mullite}$ \\
\hline UNIL_GL-B4 \#2 & 1400 & 7 & 145 & Tlc-Pxrex-MgO & B / mullite \\
\hline UNIL_GL-B4 \#3 & 1400 & 7 & 150 & Tlc-Pxrex-MgO & B / mullite \\
\hline UNIL_GL-B6 \#0 & 1500 & 7 & 60 & $\mathrm{Tlc} \mathrm{SiO}_{2}-\mathrm{MgO}$ & $\mathrm{B} / \mathrm{Al}_{2} \mathrm{O}_{3}$ \\
\hline UNIL_GL-B6 \#1 & 1500 & 7 & 75 & $\mathrm{Tlc}-\mathrm{SiO}_{2}-\mathrm{MgO}$ & $\mathrm{B} / \mathrm{Al}_{2} \mathrm{O}_{3}$ \\
\hline UNIL_GL-B6 \#2 & 1500 & 7 & 75 & $\mathrm{Tlc}-\mathrm{SiO}_{2}-\mathrm{MgO}$ & $\mathrm{B} / \mathrm{Al}_{2} \mathrm{O}_{3}$ \\
\hline UNIL_GL-B6 \#3 & 1500 & 7 & 73 & $\mathrm{Tlc} \mathrm{SiO}_{2}-\mathrm{MgO}$ & $\mathrm{B} / \mathrm{Al}_{2} \mathrm{O}_{3}$ \\
\hline UNIL_GL-B6 \#4 & 1500 & 8 & 70 & $\mathrm{TlC}-\mathrm{SiO}_{2}-\mathrm{MgO}$ & $\mathrm{B} / \mathrm{Al}_{2} \mathrm{O}_{3}$ \\
\hline UNIL_GL-B6 \#5 & 1500 & 8 & 70 & $\mathrm{Tlc}-\mathrm{SiO}_{2}-\mathrm{MgO}$ & $\mathrm{B} / \mathrm{Al}_{2} \mathrm{O}_{3}$ \\
\hline UNIL_GL-B6 \#6 & 1500 & 8 & 70 & $\mathrm{Tlc}-\mathrm{SiO}_{2}-\mathrm{MgO}$ & $\mathrm{B} / \mathrm{Al}_{2} \mathrm{O}_{3}$ \\
\hline UNIL_GL-B7\#1 & 1400 & 8 & 120 & Tlc-Pyrex-MgO & B / mullite \\
\hline UNIL_GL-B7\#2 & 1400 & 8 & 125 & Tlc-Pyrex-MgO & B / mullite \\
\hline
\end{tabular}

Tlc - talc; B refers to B-type thermocouples (TC; $\mathrm{Pt}_{94} \mathrm{Rh}_{6}-\mathrm{Pt}_{70} \mathrm{Rh}_{30}$ ) 
Table 3

Major element (wt\%), $\mathrm{Cl}(\mathrm{wt} \%)$ and $\delta^{37} \mathrm{Cl}(\% 0)$ values of the analysed olivine hosted melt inclusions. Error on the major elements composition are described in the methodology section. Uncertainties on $\delta^{37} \mathrm{Cl}$ is the measurement error in \%o. PEC \% is the percentage of crystallization of olivine at the wall of the melt inclusion and has been estimated using the Petrolog software (Danyushevsky et al., 2000, 2002; Danyushevsky and Plechov, 2011). Each analysis given in the table corresponds to a different melt inclusion. If several melt inclusions were present in the same olivine, a letter was added at the end of the olivine name. * Major element and $\mathrm{Cl}$ concentrations from (Rose-Koga et al., 2012)

\begin{tabular}{|c|c|c|c|c|c|c|c|c|c|c|c|c|c|c|c|c|c|c|c|}
\hline & \multicolumn{19}{|c|}{ St_Vincent, SVN4b } \\
\hline & M7 & M3 & M22 & M2 & M1-a & M15-a & 60 & $90-a$ & $90-b$ & 176 & $186-a$ & 164 & $171-a$ & M36 & M24 & $90 v$ & 184 & $181-a$ & $181-b$ \\
\hline PEC & 6.2 & 7.8 & 3.3 & 17.0 & 14.5 & 7.1 & 5.8 & 7.3 & 4.5 & 4.4 & 6.5 & 7.8 & 4.7 & 7.4 & 3.5 & 10.8 & 9.1 & 6.5 & 19.1 \\
\hline $\mathrm{SiO}_{2}$ & 46.2 & 44.4 & 45.9 & 49.3 & 48.8 & 44.5 & 47.4 & 49.9 & 48.6 & 45.3 & 44.7 & 44.7 & 44.9 & 50.1 & 51.4 & 50.9 & 44.1 & 48.0 & 51.2 \\
\hline $\mathrm{TiO}_{2}$ & 1.1 & 1.0 & 0.8 & 1.5 & 1.4 & 1.2 & 1.1 & 1.5 & 0.9 & 1.3 & 1.0 & 1.3 & 1.3 & 1.5 & 1.5 & 0.9 & 1.2 & 1.0 & 1.8 \\
\hline $\mathrm{Al}_{2} \mathrm{O}_{3}$ & 19.1 & 18.3 & 18.2 & 14.0 & 14.6 & 18.8 & 18.8 & 18.7 & 18.8 & 19.0 & 19.2 & 17.9 & 18.2 & 17.1 & 18.1 & 17.7 & 17.7 & 19.2 & 12.3 \\
\hline $\mathrm{FeO}$ tot & 7.8 & 11.4 & 11.4 & 12.0 & 11.8 & 9.3 & 9.1 & 7.6 & 8.1 & 7.2 & 8.9 & 8.9 & 9.5 & 9.5 & 7.5 & 8.1 & 9.8 & 9.0 & 13.0 \\
\hline MnO & 0.1 & 0.2 & 0.2 & 0.2 & 0.2 & 0.1 & 0.2 & 0.1 & 0.0 & 0.1 & 0.1 & 0.1 & 0.1 & 0.2 & 0.1 & 0.1 & 0.1 & 0.1 & 0.2 \\
\hline MgO & 9.2 & 9.1 & 6.4 & 10.8 & 10.2 & 8.1 & 8.0 & 8.0 & 8.2 & 7.3 & 7.6 & 8.6 & 7.4 & 7.8 & 7.1 & 8.7 & 9.0 & 7.3 & 11.1 \\
\hline $\mathrm{CaO}$ & 13.4 & 12.3 & 13.9 & 8.4 & 9.3 & 14.7 & 11.5 & 9.9 & 10.2 & 15.7 & 13.7 & 15.0 & 15.0 & 9.6 & 10.1 & 9.0 & 14.6 & 11.9 & 6.8 \\
\hline $\mathrm{Na}_{2} \mathrm{O}$ & 2.7 & 2.8 & 2.7 & 3.3 & 3.1 & 3.0 & 3.3 & 3.7 & 4.5 & 3.5 & 4.5 & 3.1 & 3.2 & 3.7 & 3.7 & 3.8 & 3.1 & 3.0 & 2.9 \\
\hline $\mathrm{K}_{2} \mathrm{O}$ & 0.3 & 0.3 & 0.3 & 0.4 & 0.4 & 0.3 & 0.4 & 0.5 & 0.6 & 0.4 & 0.3 & 0.3 & 0.3 & 0.5 & 0.5 & 0.7 & 0.4 & 0.4 & 0.6 \\
\hline $\begin{array}{c}\mathrm{Cl} \\
\text { EMPA }\end{array}$ & 0.10 & 0.13 & 0.11 & 0.10 & 0.11 & 0.10 & 0.08 & 0.11 & 0.09 & 0.11 & 0.09 & 0.11 & 0.13 & 0.12 & 0.11 & 0.10 & 0.13 & 0.12 & 0.15 \\
\hline $\mathrm{Cl} / \mathrm{K} \mathbf{2 O}$ & 0.34 & 0.39 & 0.34 & 0.24 & 0.26 & 0.31 & 0.23 & 0.25 & 0.14 & 0.25 & 0.29 & 0.33 & 0.39 & 0.24 & 0.24 & 0.14 & 0.36 & 0.34 & 0.25 \\
\hline$\delta^{37} \mathrm{Cl}$ & -1.9 & -0.1 & -0.7 & -0.8 & -1.3 & -1.2 & -0.5 & -0.2 & -1.1 & -0.4 & -0.8 & 0.2 & -1.3 & -0.4 & -0.5 & -0.7 & -0.5 & 0.6 & -1.7 \\
\hline $2 \mathrm{sd}$ int & 0.5 & 0.3 & 0.3 & 0.4 & 0.3 & 0.3 & 0.5 & 0.3 & 0.3 & 0.4 & 0.4 & 0.2 & 0.3 & 0.3 & 0.4 & 0.3 & 0.3 & 0.3 & 0.2 \\
\hline Fo & 89 & 85 & 79 & 85 & 85 & 86 & 86 & 88 & 88 & 88 & 87 & 88 & 85 & 85 & 86 & 88 & 88 & 84 & 84 \\
\hline
\end{tabular}




\begin{tabular}{|c|c|c|c|c|c|c|c|c|c|c|c|c|c|c|c|c|c|}
\hline & \multicolumn{17}{|c|}{ Aoba $(A 03, A 015, A 017)$} \\
\hline & $17-12$ & $\begin{array}{c}17-10- \\
b\end{array}$ & $\begin{array}{c}17-10- \\
c\end{array}$ & $\begin{array}{c}17-16- \\
a\end{array}$ & $\begin{array}{c}17-16- \\
b\end{array}$ & $3-9$ & $\begin{array}{c}3- \\
10 h 3-1- \\
a \\
\end{array}$ & $3-1-a$ & $3-1-b$ & 3-h1-a & 3-h1-b & 3-5 & $3-6$ & $15-1-a$ & $15-1-b$ & $\begin{array}{c}15-10- \\
a\end{array}$ & $\begin{array}{c}15-10- \\
b\end{array}$ \\
\hline PEC & 10.2 & 6.1 & 5.6 & 8.1 & 8.1 & 7.7 & 3.6 & 3.4 & 3.4 & 2.6 & 2.9 & 7.8 & 4.0 & 9.2 & 8.1 & 6.8 & 6.9 \\
\hline $\mathrm{SiO}_{2}$ & 49.8 & 50.8 & 51.7 & 49.6 & 49.6 & 46.6 & 49.4 & 51.3 & 50.2 & 46.8 & 46.9 & 48.2 & 51.1 & 49.9 & 48.8 & 50.5 & 49.6 \\
\hline $\mathrm{TiO}_{2}$ & 0.7 & 0.9 & 0.9 & 0.7 & 0.7 & 0.5 & 0.8 & 0.7 & 1.1 & 1.3 & 1.3 & 1.3 & 1.7 & 0.7 & 0.8 & 0.8 & 0.9 \\
\hline $\mathrm{Al}_{2} \mathrm{O}_{3}$ & 12.2 & 14.5 & 14.7 & 13.3 & 13.3 & 16.1 & 14.4 & 14.7 & 14.9 & 15.4 & 15.6 & 15.8 & 15.4 & 14.3 & 14.7 & 14.7 & 15.2 \\
\hline $\mathrm{FeO}$ tot & 10.5 & 9.9 & 9.5 & 10.4 & 10.4 & 10.9 & 10.9 & 12.0 & 12.6 & 13.0 & 12.7 & 12.4 & 12.4 & 9.3 & 9.4 & 9.6 & 9.8 \\
\hline MnO & 0.2 & 0.2 & 0.1 & 0.2 & 0.2 & 0.1 & 0.2 & 0.3 & 0.2 & 0.2 & 0.3 & 0.1 & 0.2 & 0.1 & 0.1 & 0.1 & 0.2 \\
\hline MgO & 10.9 & 8.5 & 8.1 & 10.1 & 10.1 & 9.8 & 9.1 & 6.3 & 6.4 & 8.5 & 8.4 & 7.2 & 6.6 & 9.6 & 9.5 & 9.0 & 8.9 \\
\hline $\mathrm{CaO}$ & 12.7 & 10.4 & 9.9 & 12.0 & 12.0 & 14.0 & 11.0 & 10.1 & 9.5 & 11.1 & 11.2 & 10.8 & 8.0 & 11.7 & 12.2 & 11.0 & 10.4 \\
\hline $\mathrm{Na}_{2} \mathrm{O}$ & 1.7 & 3.3 & 3.4 & 2.3 & 2.3 & 1.8 & 2.8 & 3.1 & 3.3 & 2.8 & 2.7 & 3.0 & 2.7 & 3.0 & 3.1 & 2.9 & 3.7 \\
\hline $\mathrm{K}_{2} \mathrm{O}$ & 1.2 & 1.3 & 1.6 & 1.3 & 1.3 & 0.3 & 1.3 & 1.5 & 1.7 & 0.9 & 0.9 & 1.1 & 1.8 & 1.4 & 1.3 & 1.4 & 1.2 \\
\hline $\mathrm{Cl}_{\text {EMPA }}$ & 0.23 & 0.32 & 0.29 & 0.25 & 0.3 & 0.06 & 0.23 & 0.31 & 0.34 & 0.3 & 0.24 & 0.39 & 0.33 & 0.32 & 0.29 & 0.21 & 0.19 \\
\hline $\mathrm{Cl} / \mathrm{K} 2 \mathrm{O}$ & 0.19 & 0.24 & 0.18 & 0.19 & 0.23 & 0.21 & 0.18 & 0.21 & 0.21 & 0.32 & 0.27 & 0.36 & 0.18 & 0.24 & 0.22 & 0.15 & 0.16 \\
\hline$\delta^{37} \mathrm{Cl}$ & -1.68 & -0.42 & -0.31 & -1.21 & -0.67 & -1.41 & -0.92 & -0.5 & -0.7 & -0.52 & -0.94 & 0.42 & -1.76 & -0.3 & -0.46 & -1.19 & -0.41 \\
\hline $2 s d$ int & 0.21 & 0.19 & 0.12 & 0.13 & 0.16 & 0.73 & 0.19 & 0.18 & 0.18 & 0.12 & 0.18 & 0.12 & 0.18 & 0.16 & 0.15 & 0.25 & 0.19 \\
\hline Fo & 87 & 85 & 85 & 87 & 87 & 86 & 84 & 77 & 77 & 81 & 81 & 79 & 77 & 88 & 88 & 86 & 86 \\
\hline
\end{tabular}


ACCEPTED MANUSCRIPT

\begin{tabular}{|c|c|c|c|c|c|c|c|c|c|c|c|c|}
\hline & \multicolumn{7}{|c|}{ Vulcano, Sommata } & \multicolumn{5}{|c|}{ Stromboli, Vancori Unit } \\
\hline & $S 1$ & S2 & S3 & S7-a & $S 7-b$ & s9 & $v s 1-b^{*}$ & $s 2^{*}$ & $S T 2-4$ & $S T 2-8$ & $S T 2-6$ & $S T 4-3-b$ \\
\hline PEC & 8.3 & 16.0 & 6.2 & 6.6 & 5.2 & 10.2 & 18.2 & 10.6 & 0.0 & 0.0 & 3.8 & 0.0 \\
\hline $\mathrm{SiO}_{2}$ & 48.7 & 48.3 & 49.0 & 49.0 & 49.0 & 48.2 & 47.7 & 49.8 & 53.4 & 45.9 & 57.7 & 59.2 \\
\hline $\mathrm{TiO}_{2}$ & 0.6 & 0.6 & 0.6 & 0.6 & 0.6 & 0.8 & 0.6 & 1.2 & 1.1 & 1.9 & 1.6 & 1.4 \\
\hline $\mathrm{Al}_{2} \mathrm{O}_{3}$ & 10.8 & 10.4 & 10.7 & 10.5 & 10.5 & 10.8 & 10.5 & 16.2 & 14.8 & 18.0 & 15.3 & 17.1 \\
\hline FeO tot & 9.5 & 9.9 & 9.0 & 9.3 & 9.2 & 10.1 & 10.1 & 10.2 & 11.8 & 10.7 & 7.3 & 4.4 \\
\hline MnO & 0.2 & 0.2 & 0.2 & 0.2 & 0.2 & 0.2 & 0.1 & 0.2 & 0.2 & 0.2 & 0.1 & 0.1 \\
\hline MgO & 11.8 & 13.3 & 11.8 & 11.4 & 11.2 & 11.8 & 14.3 & 7.9 & 6.6 & 5.5 & 2.0 & 0.8 \\
\hline $\mathrm{CaO}$ & 14.8 & 13.4 & 14.9 & 15.2 & 15.3 & 14.5 & 12.7 & 8.2 & 5.0 & 12.0 & 7.8 & 6.1 \\
\hline $\mathrm{Na}_{2} \mathrm{O}$ & 2.0 & 2.1 & 2.0 & 2.1 & 2.1 & 1.7 & 1.9 & 2.9 & 3.7 & 3.5 & 3.6 & 3.9 \\
\hline $\mathrm{K}_{2} \mathrm{O}$ & 1.6 & 1.8 & 1.7 & 1.7 & 1.7 & 1.9 & 1.7 & 2.9 & 3.3 & 2.3 & 4.4 & 4.5 \\
\hline Cl EMPA & 0.38 & 0.37 & 0.40 & 0.44 & 0.43 & 0.33 & 0.35 & 0.14 & 0.15 & 0.46 & 0.29 & 0.22 \\
\hline $\mathrm{Cl} / \mathrm{K} 2 \mathrm{O}$ & 0.23 & 0.21 & 0.23 & 0.26 & 0.25 & 0.17 & 0.21 & 0.05 & 0.05 & 0.20 & 0.07 & 0.05 \\
\hline$\delta^{37} \mathrm{Cl}$ & -2.29 & -2.83 & -2.5 & -2.15 & -2.00 & -2.23 & -3.41 & -1.75 & -2.85 & -1.38 & -2.27 & -3.18 \\
\hline $2 s d$ int & 0.20 & 0.10 & 0.10 & 0.10 & 0.09 & 0.14 & 0.16 & 0.28 & 0.18 & 0.19 & 0.19 & 0.12 \\
\hline Fo & 90 & 91 & 91 & 90 & 90 & 89 & 89 & 83 & 69 & 71 & 66 & 69 \\
\hline
\end{tabular}


Table 4

SIMS analytical conditions

\begin{tabular}{|c|c|}
\hline Effective field of view $(\mu \mathrm{m})$ & 80 \\
\hline Field aperture $(\mu \mathrm{m})$ & 4000 \\
\hline Entrance slit $(\mu \mathrm{m})$ & 122 \\
\hline Exit slit multicoll & $\# 1$ \\
\hline Contrast aperture $(\mu \mathrm{m})$ & 400 \\
\hline Energy slit $(\mathrm{eV})$ & 50 \\
\hline L4 aperture $(\mu \mathrm{m})$ & 200 \\
\hline
\end{tabular}


Table 5

$\delta^{37} \mathrm{Cl}$ measured by SIMS in the different run of synthesized glasses (UNIL_GL-B4, UNIL_GL-B6 and UNIL_GL-B7) during two sessions. All values from the first session were corrected on the basis of the difference between the two sessions on the same sample (UNIL_GL-B7\#1 for UNIL_GL-B7 and UNIL_GL-B6\#3 for the UNIL_GL-B6), in order to allow comparison of all data.

\begin{tabular}{|c|c|c|c|c|}
\hline & $\begin{array}{c}\delta^{37} \mathrm{Cl}(\%) \\
\text { session } 1 \\
(21.01 .15) \\
\end{array}$ & $\mathbf{n}$ & $\begin{array}{c}\delta^{37} \mathrm{Cl}(\%) \\
\text { session } 2 \\
(14.08 .15) \\
\end{array}$ & $\mathbf{n}$ \\
\hline UNIL_GL-B4\#1 & $8.57 \pm 0.35$ & 17 & n.d. & 0 \\
\hline UNIL_GL-B4\#2 & $8.49 \pm 0.30$ & 8 & n.d. & 0 \\
\hline UNIL_GL-B4\#3 & $8.56 \pm 0.28$ & 10 & n.d. & 0 \\
\hline $\begin{array}{l}\text { UNIL_GL-B4 } \\
\text { summary }\end{array}$ & \multicolumn{4}{|c|}{$8.55 \pm 0.31(n=35)$} \\
\hline UNIL_GL-B6 \#0 & n.d. & 0 & $5.83 \pm 0.20$ & 6 \\
\hline UNIL_GL-B6\#1 & $5.77 \pm 0.37$ & 10 & n.d. & 0 \\
\hline UNIL_GL-B6\#2 & $5.89 \pm 0.41$ & 10 & n.d. & 0 \\
\hline UNIL_GL-B6\#3 & $5.73 \pm 0.18$ & 10 & $5.73 \pm 0.27$ & 2 \\
\hline UNIL_GL-B6 \#4 & n.d. & 0 & $5.78 \pm 0.27$ & 8 \\
\hline UNIL_GL-B6 \#5 & n.d. & 0 & $5.83 \pm 0.06$ & 4 \\
\hline $\begin{array}{c}\text { UNIL_GL-B6 \#6 } \\
\text { UNIL_GL-B6 } \\
\text { summary } \\
\end{array}$ & \multicolumn{4}{|c|}{$5.8 \pm 0.21(n=56)$} \\
\hline UNIL_GL-B7 \#1 & $5.70 \pm 0.15$ & 10 & $5.71 \pm 0.12$ & 12 \\
\hline $\begin{array}{c}\text { UNIL_GL-B7 \#2 } \\
\text { UNIL_GL-B7 } \\
\text { summary }\end{array}$ & \multicolumn{4}{|c|}{$5.7 \pm 0.12(n=40)$} \\
\hline
\end{tabular}




\section{Figure captions}

\section{Figure 1 (1 column)}

$\delta^{37} \mathrm{Cl}$ composition of different mantle reservoirs and crustal sources. The grey field corresponds to the measured $\delta^{37} \mathrm{Cl}$ of melt inclusions from this study. ${ }^{1}$ John et al. (2010); ${ }^{2}$ Sharp et al. (2007), Bonifacie et al. (2008b); ${ }^{3}$ Ransom et al. (1995); Spivack et al. (2002); Godon et al. (2004b, 2004c); Bonifacie et al. (2007a); ${ }^{4}$ Barnes et al. (2009a, 2008) ; ${ }^{5}$ Barnes and Cisneros (2012) ; ${ }^{6}$ Barnes and Sharp (2006); Barnes et al. (2006, 2008, 2009a); Bonifacie et al. (2008a); Barnes et al. (2014).

\section{Figure 2 ( 2 columns)}

$\delta^{37} \mathrm{Cl}$ measured by SIMS for the 7 different glass synthesis runs for composition UNIL_GL-B6. The error bars represent the measurement errors $(2 \sigma)$ determined for each analysis, the black line is the mean. The dashed line represent the 2 SD on the reproducibility calculated for all the UNIL_Gl-B6 grains from the different runs during the all SIMS session.

\section{Figure 3 (1 column)}

Individual point measurement errors (internal error) of the measured chlorine isotope values in melt inclusions as a function of their $\mathrm{Cl}$ concentration.

\section{Figure 4 ( 2 columns)}

Instrumental mass fractionation (IMF) compared to different major elements of glass standards. Error bars represent total uncertainty (2SD). The multi-element fit for IMF in Figure 5 yields a vastly more accurate means to correct for IMF. In this SIMS session $\mathrm{K}_{2} \mathrm{O}$ is mainly responsible for the IMF, but it is not the case for all the sessions.

\section{Figure 5 (1 column)}


IMF as a function of major element composition $\left(\mathrm{SiO}_{2}, \mathrm{Al}_{2} \mathrm{O}_{3}\right.$ and $\left.\mathrm{K}_{2} \mathrm{O}\right)$ of the 6 glass standards. Error bars are the propagated error of the SIMS measurement reproducibility and error for the Pyro-IRMS measurements.

\section{Figure 6 ( 2 columns)}

Chorine isotopes of melt inclusions, compared to their $\mathrm{Cl} / \mathrm{K}_{2} \mathrm{O}$ ratio. Error bars $(2 \sigma)$ represent individual analysis uncertainty (measurement error). The black dots on the curves correspond to the $\%$ of fluids addition. The different end-members used for the model are discussed in the text. 
Fig. 1

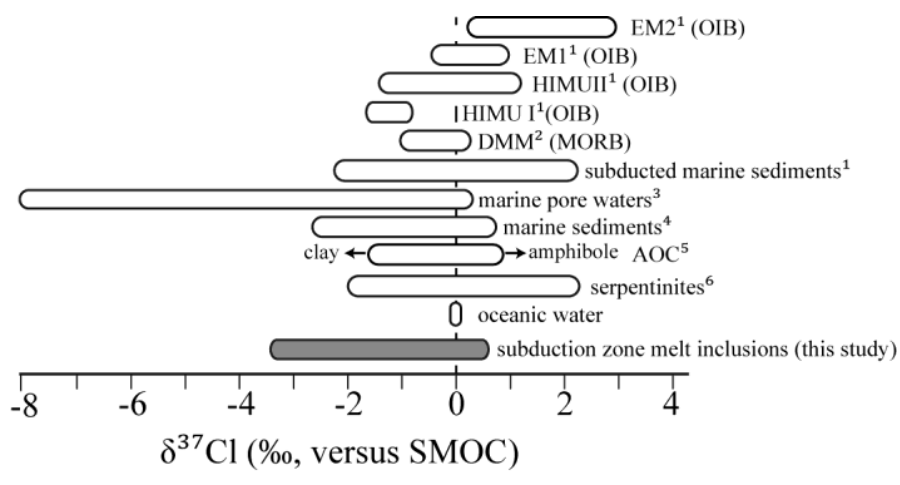


Fig. 2

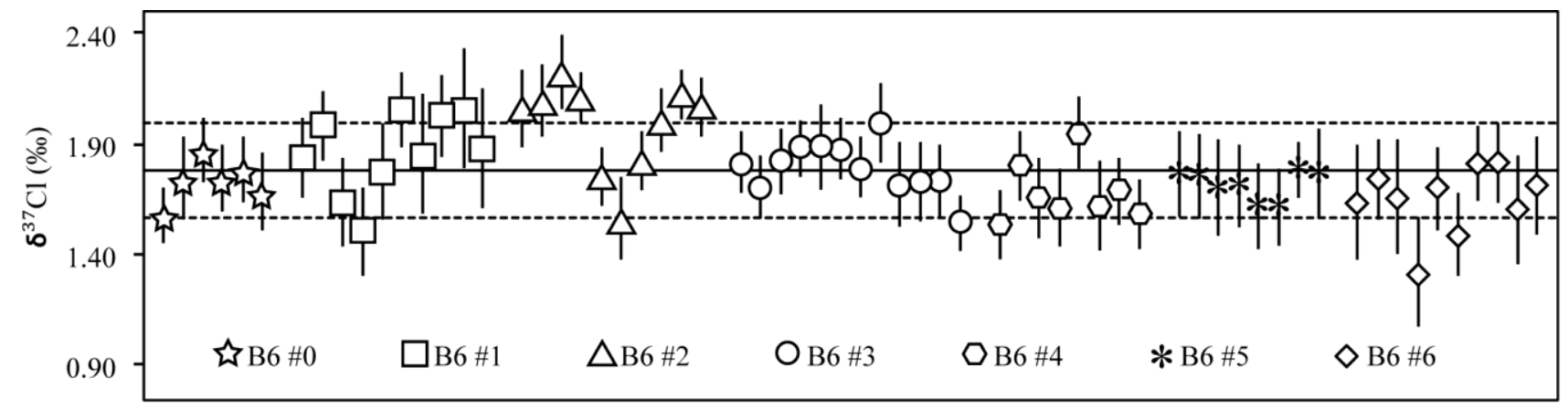


Fig. 3

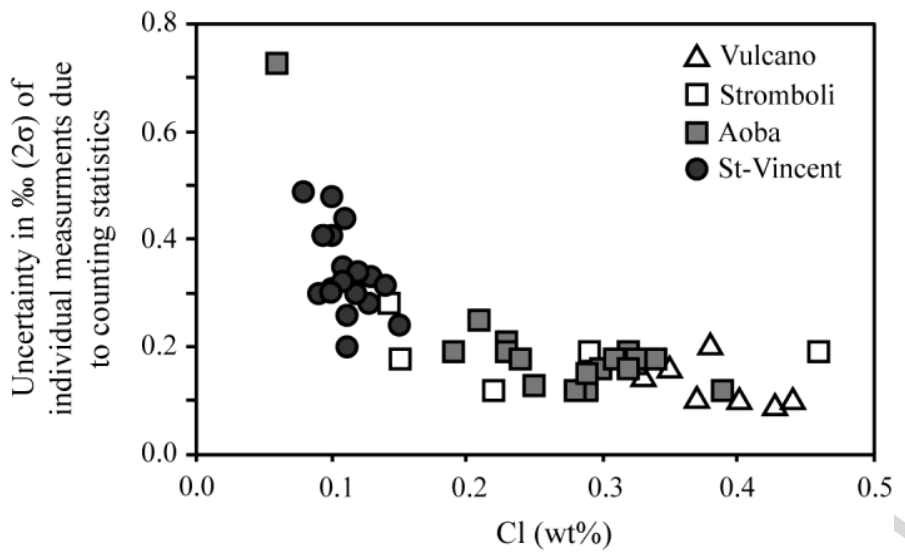


Fig. 4

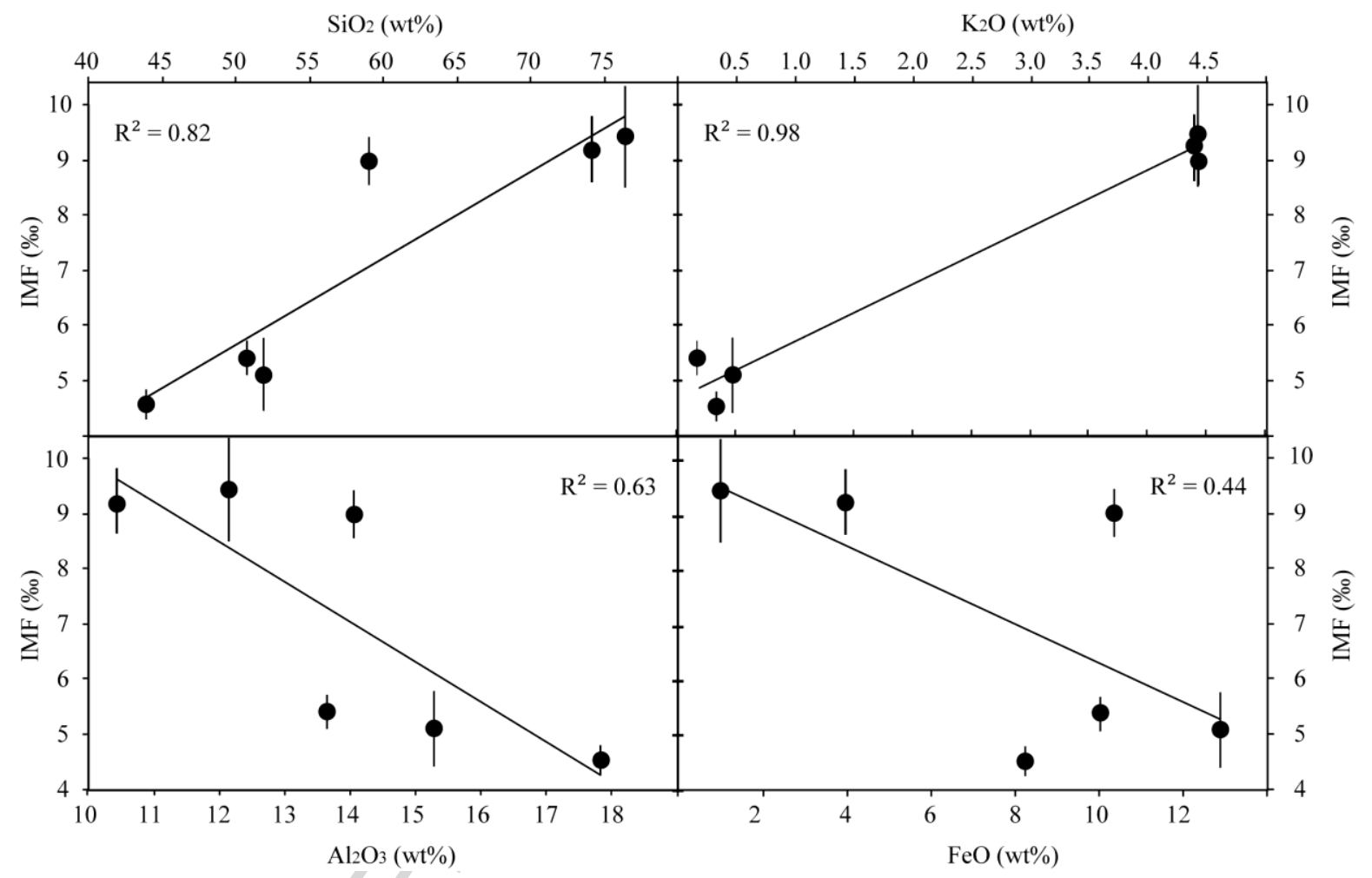


Fig. 5

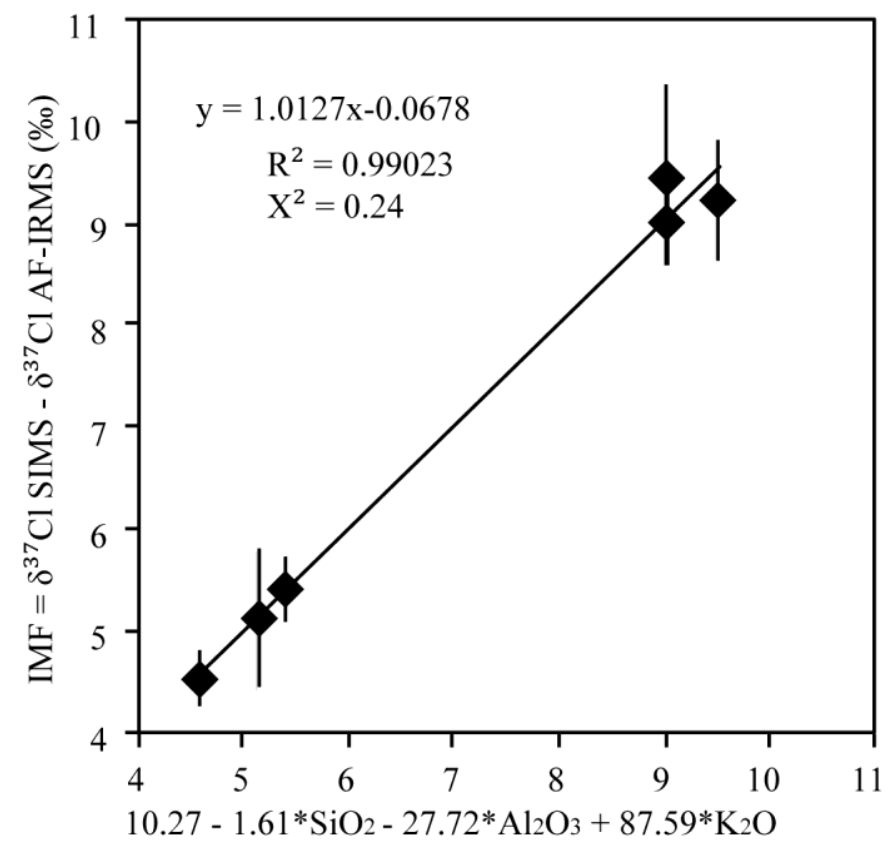

(moles) 
Fig. 6

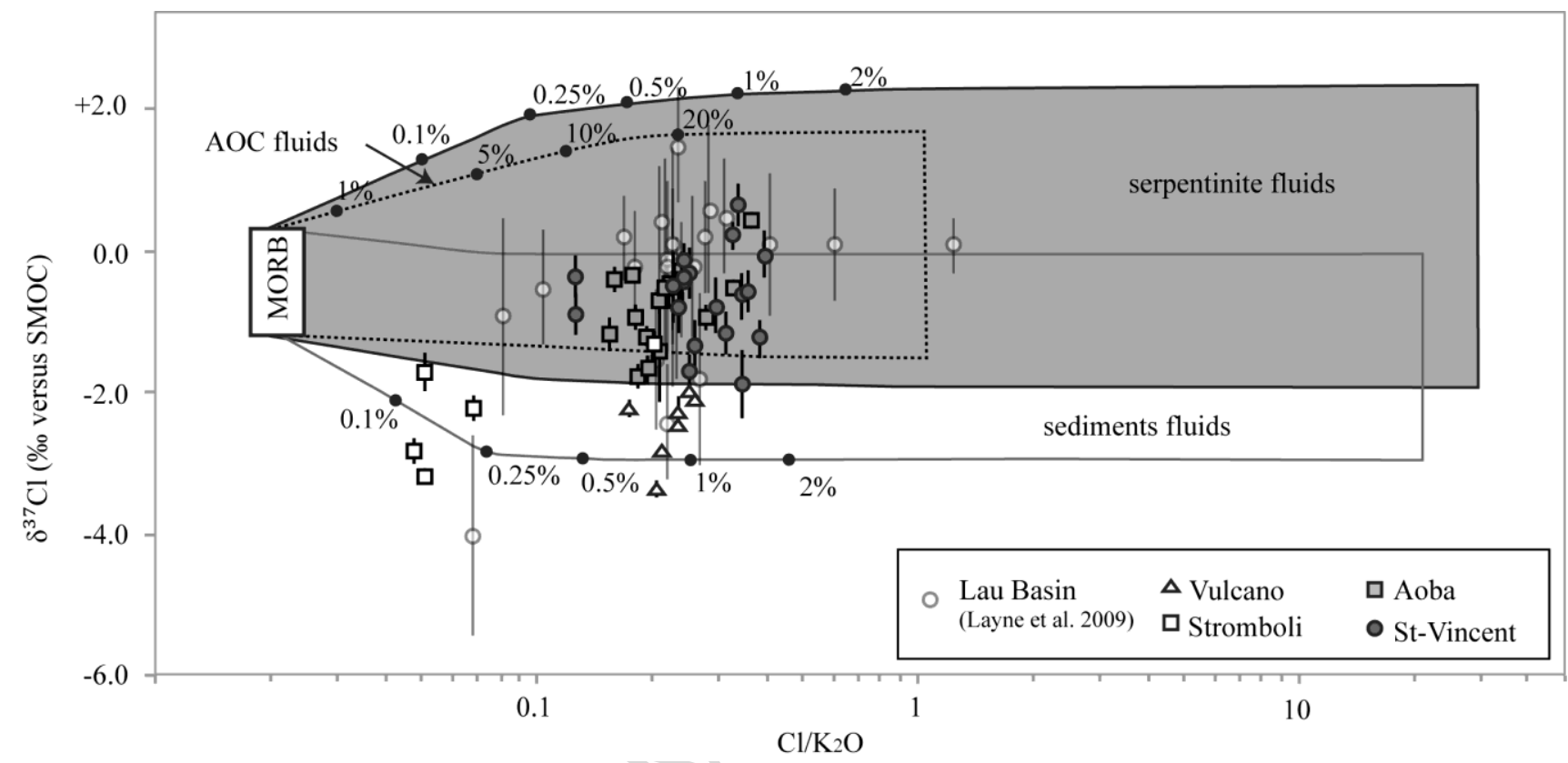




\section{Highlights}

SIMS allows $\delta^{37} \mathrm{Cl}$ measurements in glass with reproducibilities better than $0.3 \%$ (2SD) Large $\delta^{37} \mathrm{Cl}$ variations ( $>4.0 \%$ ) are observed in volcanic arc melt inclusions Distinct $\delta^{37} \mathrm{Cl}$ signatures are observed between the different volcanic arcs $\delta^{37} \mathrm{Cl}$ signatures of melt inclusions depends on the thermal structure of the slab 